\title{
Statutory Regulation of Professional Journalism Under European Data Protection: Down But Not Out?
}

\section{David Erdos}

University Lecturer in Law and the Open Society, Faculty of Law \& WYNG Fellow in Law, Trinity Hall, University of Cambridge

Email: doe20@ cam.ac.uk ${ }^{1}$

\section{Abstract:}

European data protection aims to protect the privacy and related rights of individuals, purposes which come into tension with the free speech of professional journalism.

Moreover, statutory Data Protection Authorities (DPAs) act as the 'guardians' of the data protection framework across the European Economic Area. In light of this, the article explores the enforcement efforts of these critical actors through both a DPA questionnaire and a DPA website review. The results indicate that, notwithstanding stringent statutory provisions enforceable by DPAs in many Member States, activity has been patchy even in areas which raise limited free speech concern (e.g. tackling significant inaccuracy). Nevertheless, many DPAs do engage in this area especially when sensitive or important confidential information is involved. The stringency of local law also positively correlates with the extent of enforcement, whilst the level of resourcing surprisingly does not. The article proposes action by both Member States and DPAs to ensure more regulatory coherence under the forthcoming General Data Protection Regulation.

\section{ARTICLE HISTORY; Received 7 August 2016; Accepted 4 October 2016}

Keywords: European harmonization, EU Charter, freedom of expression, General Data Protection Regulation, media regulation.

\footnotetext{
${ }^{1}$ I would like to thank those who aided the research presented here including, in particular, the Data Protection Authorities (DPAs) who participated in the 2013 questionnaire, the large number of research assistants especially those who helped collect material for the DPA website review and also the anonymous reviewer. This work was supported by the British Academy under Grant SG112737. All views and any errors remain my own.
} 


\section{Introduction}

European Union data protection aims to create a common European space for the processing of personal data within which 'the fundamental rights and freedoms of natural persons, and in particular their right to privacy' are safeguarded. ${ }^{2}$ In contrast, as a central instance of freedom of expression, professional journalism aims to gather, organize and disseminate a wide variety of information to a broad and unrestricted public. Given this, the EU data protection regime and journalistic freedom coexist within a state of serious and fundamental tension. The Data Protection Directive 95/46 substantively addressed this tension by requiring European Economic Area (EEA) ${ }^{3}$ Member States to 'balance between fundamental rights ${ }^{4}$ here, whilst still ensuring that an 'equivalent' ${ }^{5}$ standard of data protection throughout Europe was attained. Since 2009, these requirements have been given added legal emphasis by recognition of data protection, privacy and freedom of expression as fundamental rights within the EU Charter, ${ }^{6}$ together with the protection of the former within the EU treaties ${ }^{7}$ themselves. In contrast, Member States transposed the Directive's journalism provisions in highly divergent ways, with many retaining the applicability of a wide variety of sometimes onerous data protection standards even in the professional journalistic sector.

\footnotetext{
${ }^{2}$ Directive 95/46, art. 1.

${ }^{3}$ Although Directive 95/46 itself only refers to the EU, European Economic Area law extends its provisions to three associated states (Iceland, Liechtenstein and Norway) which, together with the EU, comprise the EEA. See EEA Joint Committee, Decision 84/1999 of 25 June 1999 amending Protocol 37 and Annex XI

(Telecommunication Services) to the EEA Agreement. The precise relationship between the legal duties of Iceland, Liechtenstein and Norway and both related legal provisions such the protection of data protection within the EU treaties and interpretations of data protection by the Court of Justice of the European Union remains a matter of great complexity, the consideration of which is beyond the scope of this article. Following the results of a referendum on 24 June 2016, the UK Government is now committed to the country (together with the UK's intra-EU overseas territory of Gibraltar) leaving the EU. Its position on continued membership of the EEA remains more ambiguous. For now, however, the UK remains a full member of the EU, as it was when the data presented in this article was collated.

${ }^{4}$ Directive 95/46, recital 37.

${ }^{5}$ Directive 95/46, recital 8.

${ }^{6}$ EU Charter of Fundamental Rights, art 8, 7 and 11.

${ }^{7}$ TFEU, art 16 (1).
} 
Alongside their substantive stipulations, both the EU Charter and Directive 95/46 require one or more statutory Data Protection Authorities (DPAs) endowed with wideranging supervisory powers and functions to be established in each Member State. Although the Directive recognises that these powers and functions may be limited in the area of special expression, ${ }^{8}$ DPAs nevertheless are 'the main actors protecting data protection' and play 'a crucial role in processing the overwhelming majority of data protection complaints'. In light of that, this article explores the enforcement track-record of DPAs since the transposition of Directive 95/46 in the crucial, albeit complex, area of professional journalism. This is achieved through the presentation of the results of a 2013 questionnaire of EEA DPAs (to which 25 national authorities (over $80 \%$ of the total) and six regional bodies participated), together with a review of information gathered from the public websites of the same set of regulators. It also both builds upon and complements connected work which has systematically explored the statutory data protection law formally applicable to journalists in each EEA State, ${ }^{10}$ DPA interpretation within the EEA of the interface between data protection and journalistic freedom ${ }^{11}$ and both the interpretation ${ }^{12}$ and enforcement ${ }^{13}$ of data protection by EEA DPAs as regards new internet media expression by both individuals (e.g. bloggers and social network users) and organisations (e.g. search engines and rating websites).

The results indicate that DPA enforcement efforts as regards professional journalism have been much more constrained than the formal statutory provisions in Member States

\footnotetext{
${ }^{8}$ Directive 95/46, art 9 and recital 37.

${ }^{9}$ EU Agency for Fundamental Rights, Access to Data Protection Remedies in EU Member States (2013), p. 9.

${ }^{10}$ Erdos, David, 'European Data Protection and Media Expression: Fundamentally Off Balance', International and Comparative Law Quarterly, Vol. 65 (1), pp. 139-183 (2016).

${ }^{11}$ Erdos, David, 'European Regulatory Interpretation of the Interface between Data Protection and Journalism: An Incomplete and Imperfect Balancing Act?', Public Law, Issue 4, pp. 631-650 [2016].

12 Erdos, David, 'Data Protection Confronts Freedom of Expression on the "New Media" Internet: The Stance of European Regulatory Authorities, European Law Review, Vol. 40 (4), pp. 531-562 (2015).

${ }^{13}$ Erdos, David, 'European Data Protection Regulation and Online New Media: Mind the Enforcement Gaps', Journal of Law and Society (forthcoming).
} 
would suggest. Thus, not only did around only half of the DPA respondents state that they had ever undertaken enforcement here, but the great bulk of these regulators indicated that they had only intervened to uphold one or two aspects of the data protection scheme. A review of DPA websites confirmed this limited picture. At the same time, however, both sets of data highlighted that in carrying out their enforcement tasks, regulators have far from ignored the journalistic sector. To the contrary, the proportion of survey respondents who specified some action here was higher than the average level of enforcement reported as regards 'new' media actors such as social networking sites and rating websites. Meanwhile, the DPA website review disclosed significant examples of enforcement, especially as regards journalistic processing of various sensitive and related categories of data as well as of discrete types of information, such as personal identification numbers, the confidential treatment of which may be considered particularly critical to social and economic life. In sum, statutory regulation of professional journalism under European data protection may be considered 'down but not out'.

Part of the gap between statutory stipulations and the actual track record of DPAs may be explained by the desire of the latter to balance sometimes very disproportionate statutory data restrictions against journalistic free expression rights. At the same time, however, the data gathered disclosed limited activity even as regards standards such as the taking due care to ensure accuracy and to answer subject access requests, which are either generally acknowledged to be or at least DPAs themselves consider present little conflict with legitimate free speech. Correlative analysis still revealed a very strong association between stringent local statutory provisions and both the presence and extent of DPA enforcement here. In contrast, and surprisingly, this analysis disclosed no positive association between better resourcing of regulators and more activity here. This mirrors a cognate finding as regards DPA action in the 'new' internet media area where the acknowledged formal 
divergences in law between the Member States are far less marked. ${ }^{14}$ This may imply that ultimately an important factor fuelling enforcement vis-à-vis both the traditional and the 'new' media may be a DPA's own ideological commitment to intervene actively in what is obviously both controversial and difficult territory. Such a commitment may be associated with, but would ultimately be semi-autonomous from, the stringency of formal provisions found in statutory law.

From May 2018 a new General Data Protection Regulation (GDPR) is set to replace Directive 95/46 across the EEA. ${ }^{15}$ Although the GPDR's stipulations in this area are largely unchanged from that of the Directive, transition to this new framework provides a unique window of opportunity to address the various issues highlighted in this article. In crafting new law in this area, Member States should ensure that professional journalism is not entirely excluded from either substantive data protection or regulatory oversight but instead that a proportionate balance between data protection and free speech is secured across this space. Meanwhile, DPAs should focus on ensuring that their activity here achieves genuine practical effectiveness. Whilst this is largely a task for the national level, it would be valuable for the new European Data Protection Board to collectively craft a fresh Recommendation in this area aimed at ensuring both an effective and robust level of protection for data subjects and the safeguarding of legitimate free expression rights within a sector which performs an indispensable role in imparting information and ideas within all liberal democratic societies.

The rest of this article is structured into eight further sections. The two immediately following sections set out the legal context and detail both the questions and methodology of this study. Section four then presents the results from the DPA questionnaire, whilst section

\footnotetext{
${ }^{14}$ Erdos, supra note 13 .

${ }^{15}$ Regulation 2016/679 of the European Parliament and of the Council of 27 April 2016 on the protection of natural persons with regard to the processing of personal data and on the free movement of such data, and repealing Directive 95/46/EC (General Data Protection Regulation). For the Regulation's date of application see art 99 (2).
} 
five does likewise for the DPA website review. Sections six and seven then analyse these results, firstly, from a general perspective and then in order to explicate the divergences revealed between the different DPA jurisdictions. The following section shifts the focus to the future treatment of journalism in the era of the GPDR. Finally, section nine closes with some overall conclusions.

\section{Legal Context}

\section{The Default EU Data Protection Framework}

The EU data protection regime, currently centred upon framework Directive 95/46, has a surprisingly wide purposive, material and substantive reach. At least within the private sector, ${ }^{16}$ it applies to any 'personal data' which is subject to 'processing wholly or partly by automatic means' (or even which is stored in certain structured, manual filing systems). ${ }^{17}$ '[P] ersonal data' comprises 'any information relating to an identified or identifiable natural person ('data subject')', whilst 'processing ... by automatic means' encompasses 'any operation' performed digitally including collection, retrieval, consultation, dissemination and erasure. ${ }^{18}$ Meanwhile, the Directive states that its objectives are to 'protect the fundamental rights and freedoms of natural persons, and in particular their rights to privacy', at the same time prohibiting restrictions on the free flow of personal data within the EEA for reasons connected with such protection. ${ }^{19}$ Moreover, in both the EU Charter (art 8) and also the Treaty on the Functioning of the European Union (TFEU) itself (art 16), the protection of personal data has been granted fundamental right status. Reflecting its multifaceted and critical importance, data protection requires that all 'controllers' - that is anyone 'who alone

\footnotetext{
${ }^{16}$ Certain public sector tasks (for example, as regards national security) as well as 'purely personal or household activity' performed by a natural person are excluded under article 3 of the Directive.

${ }^{17}$ Directive 95/46, art 3.2.

${ }^{18} \mathrm{Ibid}$, art 2 (d).

${ }^{19} \mathrm{Ibid}$, art 1.
} 
or jointly with others determines the purposes and means of the processing of personal data 20 - by default ensures that their processing complies with a set of broad data principles centred on fairness and legitimacy, ${ }^{21}$ detailed codes to ensure the transparency of processing ${ }^{22}$ and to establish a general prohibition on the processing of 'sensitive' 23 data (including inter alia that which reveals political opinions or religious beliefs, concerns health or sex life or which relates to criminal offences or convictions) at least absent waiver by the data subject, ${ }^{24}$ and finally data security, data registration and other control mechanisms designed to ensure genuine discipline in data processing. ${ }^{25}$ Turning to the system of supervision, alongside a judicial remedy, ${ }^{26}$ Member States must establish one or more independent Data Protection Authorities (DPAs) endowed with wide-ranging powers of investigation and intervention and which are required to monitor the law's application and hear claims from data subjects. ${ }^{27}$ DPAs must also cooperate in a pan-European Article 29 Working Party which has a duty to promote 'uniform application' of Directive 95/46, notably through the issuing of official Opinions and Recommendations. ${ }^{28}$ In practice, it is these regulatory agencies which play the leading role as 'the guardians, ${ }^{29}$ of the data protection framework.

\section{Data Protection and Professional Journalism}

\footnotetext{
${ }^{20}$ Ibid, art 2 (d).

${ }^{21}$ Ibid art 6.

${ }^{22}$ Ibid, art $10-12$.

${ }^{23}$ Ibid, recital 34.

${ }^{24}$ Ibid, art 8.

${ }^{25}$ Ibid, arts 7, 17, 18-21 and 25-26.

${ }^{26}$ Ibid, art 22.

${ }^{27}$ Ibid, art 28 .

${ }^{28}$ Established under art 29 of Directive 95/46 and with tasks as set out in art 30, this group comprises a DPA representative from each of the EU Member States together with two pan-EU members, namely, the European Data Protection Supervisor and a (non-voting) representative of the European Commission. The non-EU EEA DPAs participate in the Working Party's activities as observers (see EEA Joint Committee Decision 83/1999, art 2 (see note 3$)$ ).

${ }^{29}$ C-518/07 Commission v Germany at [23].
} 
Professional journalism (herein journalism) refers to the business of producing and periodically distributing information and opinions to a large and indeterminate number of people on the basis of their real or purported quality of public interest and link to contemporary societal developments. ${ }^{30}$ As a result in particular of both its mass reach and sometimes intrusive nature, this activity can inflict 'the gravest damage on the individual, 31 thereby potentially seriously undermining data protection's central safeguarding mission. At the same time, full application of data protection's default strictures would 'radically restrict freedom of the press'. ${ }^{32}$ Article 9 of Directive 95/46 addressed this fundamental tension between data protection and journalistic purposes by stipulating that, within this area, Member States should provide for derogations from any of its substantive and most of its procedural provisions ${ }^{33}$ but 'only if they are necessary to reconcile the right to privacy with the rules governing freedom of expression'. ${ }^{34}$ Recital 37 stressed that the derogations granted should be those 'necessary for the purpose of balance between fundamental rights', should not curtail the data security obligations and should leave the supervisory authority responsible for the journalistic sector with at least 'certain ex-post powers'. Recital 8 also set out the general requirement that the level of data protection be 'equivalent in all Member States'. In 1997, these stipulations were analysed in the first ever Recommendation of the Article 29 Working Party which, although comprising only six short pages, did stress that '[d]erogations to the principles of data protection [here] ... must be in accordance with law and must respect the principle of proportionality. Equally limits to freedom of expression,

\footnotetext{
${ }^{30}$ See in this general vein Schudson, Michael, The Sociology of News (New York: Norton, 2003), 11.

${ }^{31}$ Great Britain, House of Lords, Select Committee on the European Communities, $20^{\text {th }}$ Report: Protection of Personal Data (London: HMSO 1993), 39.

${ }^{32}$ Lord Phillips of Worth Matravers in Campbell v Mirror Group Newspapers [2002] EWCA Civ 1373 [2003] QB 633 at [123].

${ }^{33}$ Article 9 excluded the possibility of derogations from the right to a judicial remedy (art 22), to compensation for damage suffered as a result of violation of the substantive rules and principles (art 23) and to the adoption of suitable measures and sanctions by Member States to ensure full implementation of the Directive (art 24).

${ }^{34}$ Article 9 similarly addressed the interface between data protection and 'the purpose of artistic or literary expression'. Whilst clearly important, further consideration of this tension falls outside the scope of analysis here.
} 
such as the ones that might derive from the application of data protection principles, must also be in accordance with the law and respect the principle of proportionality' ${ }^{35}$ This stress on proportionality was given added emphasis by the Court of Justice of the European Union (CJEU) which held in its Grand Chamber judgment of Satamedia (2008) that even in the journalistic area 'the protection of the fundamental right to privacy requires that the derogations and limitations in relation to the protection of personal data ... must apply only in so far as is strictly necessary, ${ }^{36}$

In reality, however, EU data protection's requirement for an equivalent and proportionate regime here has far from been achieved in Member State statutory law. To the contrary, extreme diversity is apparent. In sum, most Northern European jurisdictions grant journalism an overwhelming priority within their law, with some even entirely disapplying all substantive data protection safeguards here. ${ }^{37}$ Meanwhile, most Latin and Eastern European jurisdictions accord a similar priority to data protection, with a number ${ }^{38}$ granting journalism no derogations at all. A wide variety of other permutations of outcome between these extremes are also apparent. ${ }^{39}$ Turning to consider DPA supervisory powers, statutory provisions in 22 of the 31 EEA Member States, as well as the special regional case of Gibraltar, accord the ordinary DPA full regulatory powers even in the journalistic sphere. In contrast, in Malta and the United Kingdom the DPA is provided with only limited powers in this area, ${ }^{40}$ whilst Denmark and Lithuania assign such limited powers not to the ordinary

\footnotetext{
${ }^{35}$ EU, Article 29 Working Party, Recommendation 1/1997 Data Protection law and the media (1997), pp. 4-5 (http://ec.europa.eu/justice/data-protection/article-29/documentation/opinionrecommendation/files/1997/wp1_en.pdf).

${ }^{36}$ C-73/07 Tietosuojavaltuutettu v. Satakunnan Markkinapörssi Oy and Satamedia Oy, EU:C:2008:727 at [56] (emphasis added).

${ }^{37}$ This is the case in Finland (see Finland, Personal Data Act, sec 2 (5)), Norway (see Norway, Personal Data Act, sec 7), Sweden (see Personal Data Act, sec 7) and, as regards the Press, also Germany (see Germany, Federal Data Protection Act, sec 41).

${ }^{38}$ Namely, Spain, the Czech Republic and Croatia.

${ }^{39}$ See Erdos, supra note 10.

${ }^{40}$ Malta, Data Protection Act, sec 6 and United Kingdom, Data Protection Act 1998, secs 44, 46, 53 and 56.
} 
DPA but rather to a specialist body with general responsibility for media regulation. ${ }^{41}$

Meanwhile, Austria, Iceland and the Netherlands disapply regulatory enforcement here in full. $^{42}$ In the special case of Germany, both the federal DPA and many Länder DPAs have been similarly denuded of all regulatory power; nevertheless, some Länder DPAs have been granted certain limited responsibilities but only with regard to the broadcasting sector. ${ }^{43}$ Finally, in Spain, legislation grants the national DPA full regulatory powers as regards all private and most public organizations (journalistic or otherwise). ${ }^{44}$ In contrast, bodies established or operating under Basque or Catalan public law are regulated by their respective regional DPAs. ${ }^{45}$

The presence of open-textured human rights within constitutional or otherwise foundational national and European instruments adds further complexity to what is already an intricate legal landscape. Not only the European Convention on Human Rights $\left(\right.$ ECHR ${ }^{46}$ but also the great majority of Member States' constitutions grant some form of protection to both freedom of expression and to privacy. The EU Charter, which came into existence in $2000^{47}$ but was not given a formal legal status until the Treaty of Lisbon came into force in 2009 , also recognises both these rights alongside a right to data protection itself. ${ }^{48}$ A right to data

\footnotetext{
${ }^{41}$ Denmark, Law on Mass Media Information Databases, secs 12-17 and Lithuania, Data Protection Act, art 8. The bodies in question are the Danish Press Council and the Lithuanian Inspector of Journalist Ethics.

${ }^{42}$ Austria, Federal Act Concerning the Protection of Personal Data (DSG), sec 48; Iceland, Act on the Protection of Privacy as Regards the Processing of Personal Data, art 5 and Netherlands, Personal Data Protection Act, art 3.

${ }^{43}$ As regards the German DPAs including in the research presented below, such powers are only applicable in the case of Schleswig-Holstein. See Staatsvertrag über das Medienrecht in Hamburg und Schleswig-Holstein (Medienstaatsvertrag HSH), s. 37 (5)-(11).

${ }^{44}$ Spain, Organic Law 15/1999 of 13 December on the Protection of Personal Data, art 2.

${ }^{45}$ See Spain, Basque Country, Ley 2/2004, de 25 de febrero, de Ficheros de Datos de Carácter Personal de Titularidad Pública y de Creación de la Agencia Vasca de Protección de Datos, art 2; Spain, Catalonia, Ley 32/2010, de 1 de octubre, de la Autoridad Catalana de Protección de Datos, art 3.

${ }^{46}$ See arts 10 and 8, European Convention on Human Rights.

${ }^{47}$ Craig, Paul and Gráine de Búrca, EU Law: Text, Cases and Materials, 4th edn (Oxford: Oxford University Press, 2011), p. 394.

${ }^{48}$ See EU Charter, arts 11, 7 and 8. Emphasising the need for regulatory oversight in relation to data protection, the latter provision also explicitly states that 'compliance ... shall be subject to control by an independent authority'.
} 
protection is also found in the constitutions of approximately half of the EU Member States ${ }^{49}$ as well as in the post-Lisbon TFEU $U^{50}$ itself.

\section{III - Research and Methodology}

In light of the critical role which DPAs play in the realisation of data protection across the EEA, this article elucidates and explores the extent to which these entities have in fact enforced such standards within the important, albeit sensitive, area of journalism. In doing so, it primarily draws upon responses to a questionnaire sent to both national and regional ${ }^{51}$ EEA DPAs in March 2013 with replies being received until the end of July $2013 .{ }^{52}$ In order both to add context and ensure a measure of cross-checking, a review was also made of information concerning journalistic enforcement readily available on the websites of all national DPAs together with those regional bodies which responded to the questionnaire. This task, which required the use of language experts for all the various jurisdictions, was also completed during 2013. In addition, local statutory data protection law as applicable to journalism was systematically analysed and quantitatively coded; the details of this have already been published elsewhere. ${ }^{53}$

\section{The EEA Data Protection Authority Questionnaire}

\footnotetext{
${ }^{49}$ See the discussion in Joseph Cannataci and Jeanne Misfud-Bonnici, 'Data Protection Comes of Age: The Data Protection Clauses in the European Constitutional Treaty', Information and Communications Technology Law (Vol. 14 (1), pp. 5-15) (2005).

50 TFEU, art 16.

${ }^{51}$ Regional DPAs have been established in Spain and Germany as well as in Gibraltar.

${ }^{52}$ Given the survey as the whole explored not just journalism but also a range of other matters related to the tension between data protection and openness, it was decided not to separately send the survey to the specialist media regulators which in Lithuania and Denmark exercise certain powers over the media in the area of data protection (see note 41). In fact, however, the DPA's as regards journalism was filled out in cooperation with the specialist media regulator, the Inspector of Journalist Ethics. Meanwhile, the Danish DPA did not participate in the survey.

53 Erdos, supra note 10.
} 
Turning first to the construction of the questions on the enforcement track-record of DPA's as regards professional journalism, regulators were asked to indicate whether since the transposition of Directive 95/46 they had undertaken enforcement action in relation to media entities' pursuit of their journalistic activities as regards three specific provisions set out within the European data protection regime. These exemplars of specifically-targeted action were described as (i) action 'for failure to register/notify' with the DPA (which directly relates to art 18 of the Directive), (ii) action 'to ensure individuals are afforded the right to rectify inaccurate data' (which directly relates to the duty of accuracy in processing under art 6 (1) (d) and the right to rectify such data under art 12 (b)) and (iii) action 'to ensure individuals are afforded rights of data access' (which directly relates to art 12 (a) of the Directive). In order to assess more diffusely targeted action, DPAs were also invited to indicate whether they had taken (iv) action 'to prevent the processing/publication of personal data obtained without proper authorization from another Data Controller' as well as (v) action 'to prevent the processing/publication of personal data in contexts other than when data was obtained without authorization from another Data Controller'. The distinction drawn between (iv) and (v) was based on the understanding that enforcement falling within the former category - where information is obtained without authorization from another data controller - could, other things being equal, be considered to intrude less directly on media freedom of expression than that within the second category, where the data would have been obtained either with consent (e.g. an interview transcript) or have been generated by the media itself (e.g. a photograph). This reflects both that the unauthorized obtaining of the information often requires recourse to generally invidious mechanisms such as corruption or blagging $^{54}$ and also that another data controller will necessarily be processing this data for their own discrete purposes (e.g. medical care in the case of a doctor's practice) which will

\footnotetext{
${ }^{54}$ UK, Information Commissioner's Office, What Price Privacy? (2006), passim (https://ico.org.uk/media/about-the-ico/documents/1042393/what-price-privacy.pdf).
} 
often be seriously undermined by publication. Finally, DPAs who had not signified assent to any of the above were invited to positively indicate that they had 'not taken any enforcement action in relation to media entities' pursuit of their journalistic activities'.

The questionnaire also gathered responses from DPAs on related matters including their enforcement efforts as regards 'new' internet media activity (e.g. blogs, rating websites and street mapping services) and the financial resources they had available for data protection activity. Whilst the detail of these more tangentially related parts of the survey has been written up elsewhere, ${ }^{55}$ relevant findings will be referred to in the analysis sections of this article where appropriate. Prior to this, however, the next two sections elucidate the article's core findings as regards the track-record of DPAs in the journalistic sphere.

\section{IV- EEA DPA Questionnaire Findings}

In total replies to the questionnaire were received from 25 (over 80\%) of national EEA DPAs, together with a further six operating at the regional level. However, included within these 31 returns were five non-standard responses. In sum, four DPAs (those in the Czech Republic, Bulgaria, Malta and the UK) did not answer the questions directly posed but rather provided their own free-text answer. Meanwhile, the Luxembourg DPA provided an seemingly inconsistent response, indicating both that it had 'taken action to prevent the processing/publication of personal data in contexts other than when such data was obtained without authorization from another Data Controller' and that it had 'not taken any enforcement action in relation to media entities' pursuit of their journalistic activities' ${ }^{56}$

\footnotetext{
${ }^{55}$ See Erdos, supra notes 12 and 13.

${ }^{56}$ It should also be noted that the Greek DPA slightly altered the wording of the two pre-formulated responses it indicated assent to. In sum, both as regards material obtained without authorization from another Data Controller and otherwise, it replaced the phrase 'action to prevent the processing/publication of personal data' with 'action to erased the published personal data'. It was felt, however, that this would still constitute enforcement in relation to 'processing' and that, therefore, a standard response could still be recorded here.
} 
Therefore, whilst these non-standard responses will be considered from a qualitative viewpoint where relevant, only the 26 standard replies received are included in the quantitative results below.

As Chart One indicates, the extent of activity reported varied considerably between the different aspects of data protection being explored. Very few DPAs reported any enforcement in relation to the specific aspects of EU data protection requirements which were cited. Thus, only one response ( $4 \%$ of the total) indicated action 'for failure to register/notify', four (15\%) action 'to ensure individuals are afforded the right to rectify inaccurate data, ${ }^{57}$ and five (19\%) action 'to ensure individuals are afforded rights of data access'. In some contrast, turning to more generalized enforcement, ${ }^{58}$ ten $(38 \%)$ reported undertaking action 'to prevent the processing/publication of personal data obtained without proper authorization from another Data Controller' and seven (27\%) 'action to prevent the processing/publication of personal data in contexts other than when data was obtained without authorization from another Data Controller'. ${ }^{59}$ These figures are reported at the level of each DPA in the appendix to this article.

\footnotetext{
${ }^{57}$ As regards the free-text responses, the Bulgarian DPA did indicated that it had conducted 'inspections and follow-up imposition of administrative penalties to paper media in connection with ... publishing of false information about publicly known person in order to discredit him'.

${ }^{58}$ As regards the free-text responses, the Bulgarian DPA indicated that it conducted 'inspections and follow-up imposition of administrative penalties to paper media' in connection with both 'unlawful personal data dissemination (including of special categories of data) without individuals' knowledge and consent' and 'excessive personal data processing by media by publishing bigger amounts of individuals' personal data then [sic] necessary for the performance of journalistic investigations and lack of adequate technical and organization measure for protecting the data against unlawful dissemination'. The Czech DPA stated that it had 'taken an action to remove an article containing personal data from the electronic media'. Meanwhile, the Maltese DPA stated that it had 'taken action to ensure removal of contents from journalistic blogs or media-related internet publications which involved the unlawful processing of personal data'. Finally, the UK DPA stated that that whilst it had not undertaken enforcement action 'in the sense of issuing enforcement notices or monetary penalties' had undertaken 'other forms of regulatory action' including 'most notably' publishing 'two reports on the use of private investigators by the media' which 'focused on the unauthorized obtaining of personal information in pursuit of journalistic activity'.

${ }^{59}$ As detailed in footnote 56, the Greek DPA slightly altered the wording of both these responses but not in ways which would take the answer provided outside the scope of the broad concept of 'processing'.
} 
Chart One: Enforcement of Particular Aspects of Data Protection vis-à-vis the

\section{Professional Journalism (n=26)}

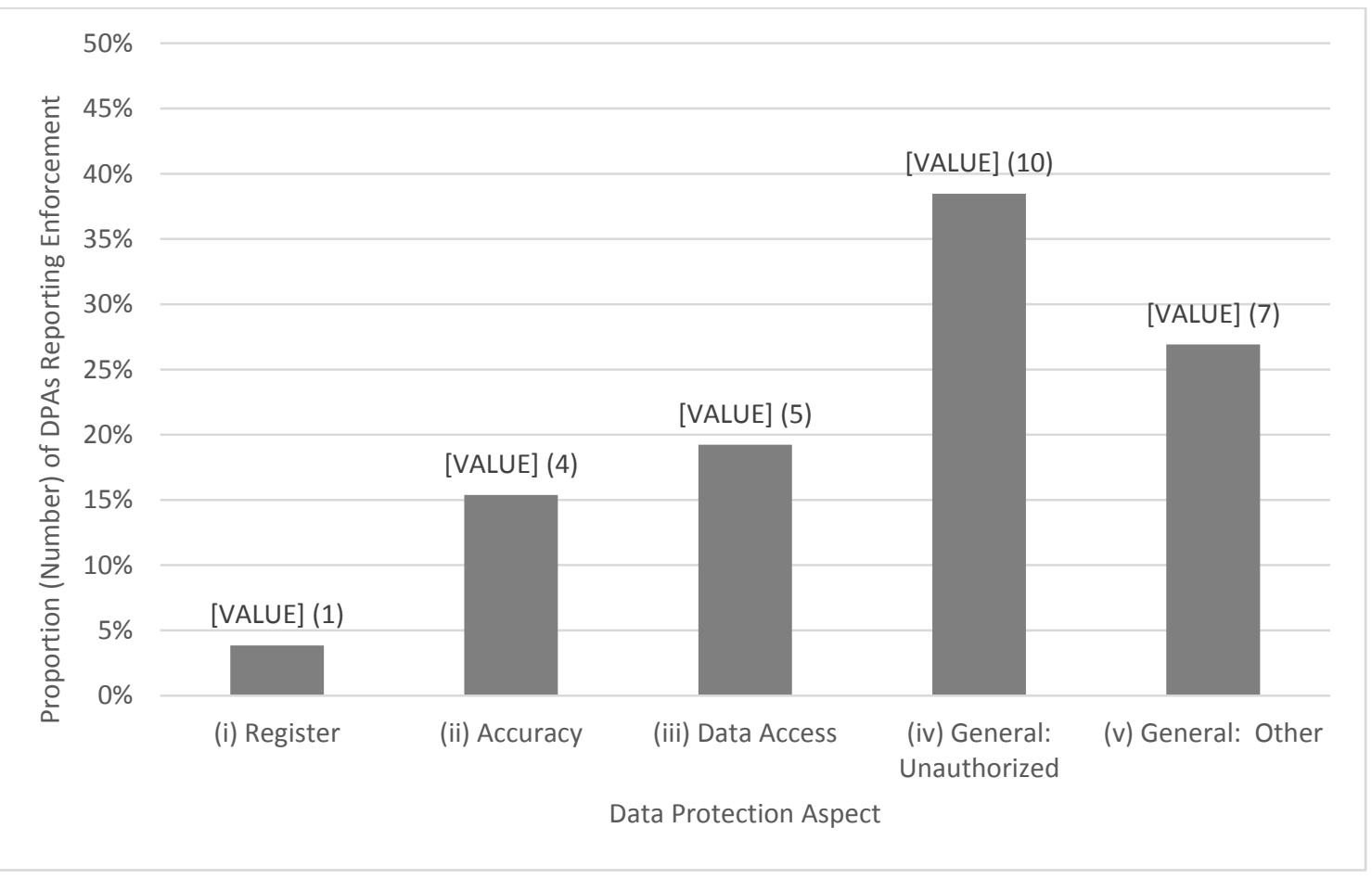

The extent of enforcement reported by each DPA also diverged substantially. As Chart Two below illustrates, twelve DPAs $(46 \%)$ reported no enforcement at all, ${ }^{60}$ thereby leaving fourteen $(54 \%)$ which did indicate some action. Nevertheless, as is also clear, the great majority of these DPAs reported only a limited range of activity. Indeed, eleven of these DPAs (42\%) testified to enforcement only as regards one or two aspects inquired about, leaving only three DPAs (12\%) who signalled more extensive activity. Finally, not one DPA reported undertaking enforcement as regards all five aspects specified. Again, these total figures are set out at the level of each DPA in the appendix to this article.

\footnotetext{
${ }^{60}$ All these DPAs not only indicated no activity as regards any of the enforcements specified (i.e. (i)-(v)) but also positively assented to the statement that they 'had not taken any enforcement action in relation to media entities' pursuit of their journalistic activities'. Nevertheless, the French DPA did state that it had 'taken other action [not constituting enforcement] such as educational measures'.
} 
Chart Two: Extent of reported DPA enforcement as regards particular aspects of data protection vis-à-vis professional journalism $(n=26)$

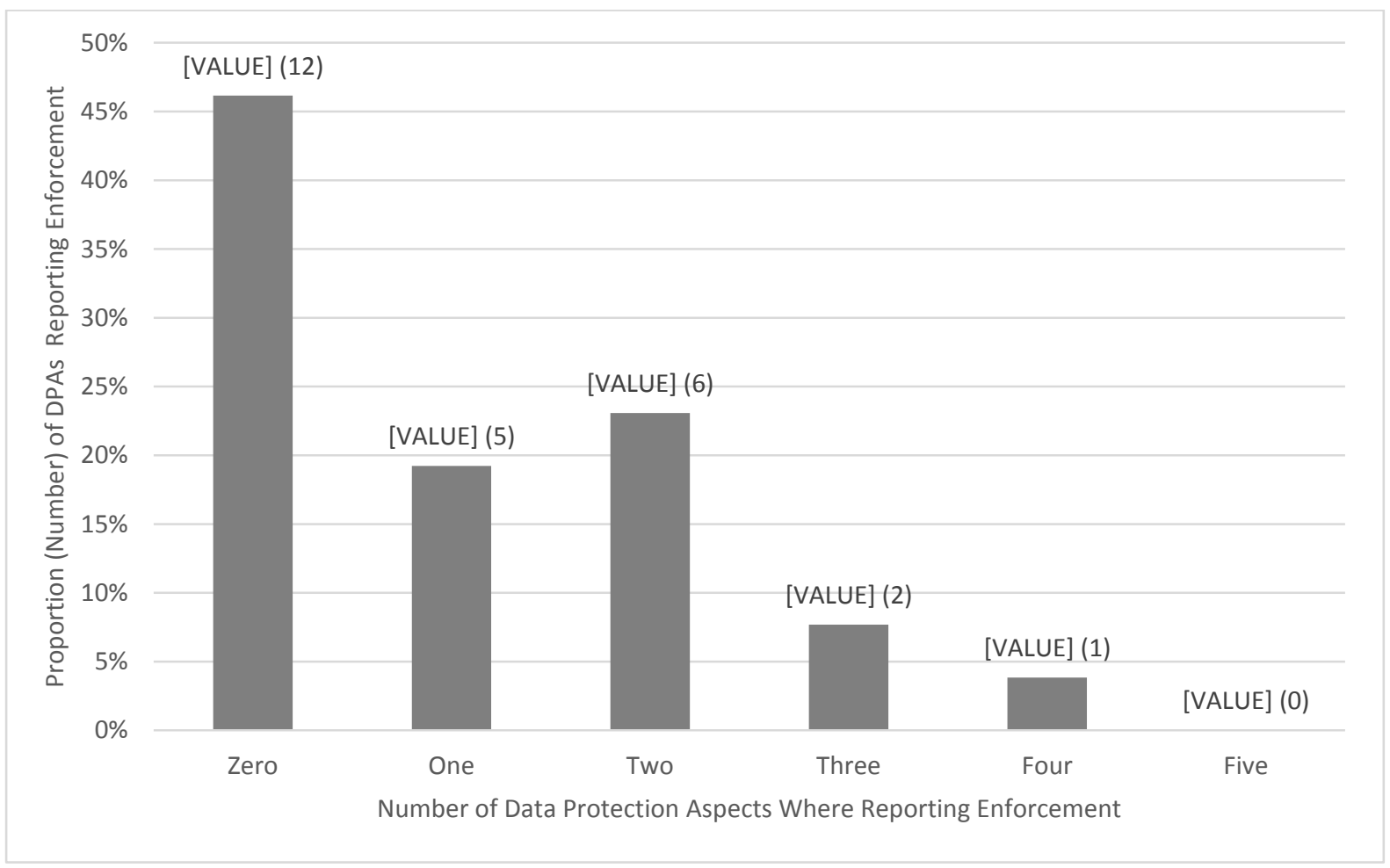

\section{V - EEA DPA Website Review Findings}

As previously noted, in order both to add context to and to ensure a measure of crosschecking of the self-reported questionnaire responses, an attempt was made during 2013 to collate reports of enforcement action ${ }^{61}$ readily accessible on the websites of all national EEA DPAs ${ }^{62}$ together with those regional regulators which responded to the survey. However, it became clear during this exercise that the very different way in which DPAs approached the issue of online reporting, retaining and collating of information made the creation of a fully

\footnotetext{
${ }^{61}$ The meaning of 'enforcement activity' was not explicitly defined in the survey itself. However, as regards the DPA website review, it was taken to refer any type of action which clearly went beyond purely investigatory activity or the issuing of 'soft' non-binding guidance to data controllers.

${ }^{62}$ In the case of Denmark and Lithuania this also involved the checking of the websites of the Danish Press Council and Lithuanian Inspector of Journalism Ethics respectively.
} 
systematic and detailed dataset impossible. ${ }^{63}$ Notwithstanding these limitations, however, the data which was collated tended to confirm the picture outlined in the previous section of patchy and limited, yet also clearly far from irrelevant, enforcement actions by DPAs within the journalistic sector. This section provides an overview of this data.

Turning first to consider results from the websites of those DPAs which returned a response in a standard format, evidence of enforcement within the area of professional journalism since the transposition of Directive 95/46 was found in eight (31\%) cases (namely the Cypriot, Greek, Hungarian, Irish, Italian, Netherlands and Slovenian DPAs as well as the Lithuanian DPA/Inspector of Journalism Ethics). ${ }^{64}$ Whilst the DPAs in all of these cases also self-reported enforcement activity, this value is clearly lower than the fourteen DPAs (54\%) which indicated in the survey that they had carried out enforcement activity. Nevertheless, this discrepancy may be explained not only by the fact that only website material which was readily accessible was collated but also by the reality that many DPA websites in any case only publicized prominent, as opposed to all, examples of enforcement action ${ }^{65}$ and, in

\footnotetext{
${ }^{63}$ There have been sporadic efforts to improve and render more systematic the transparency of DPA decisionmaking. For example, in 2009 the International Conference of Data Protection and Privacy Commissioners even agreed to a Resolution on this topic (International Conference of Data Protection and Privacy Commissioners, Resolution on Case Reporting (2009) (https://icdppc.org/wpcontent/uploads/2015/02/Resolution-on-Case-Reporting.pdf). It is clear that such a goal remains, at best, a work-in-progress even within the EU.

${ }^{64}$ In addition, as regards the Belgium DPA website, evidence was found of enforcement as regards newspaper archives only (see Belgian, Commission de la Protection de la vie privée, Rappport annuel 2011, pp. 52-53 (https://www.privacycommission.be/sites/privacycommission/files/documents/rapport-annuel-2011.pdf). However, since the focus of the article here is on traditional, professional journalism and a different part of the survey focused on 'newspaper archives' this (as well as other DPA website examples of enforcement activity specifically focused on archives) were excluded from the analysis. Meanwhile, in Latvia evidence of two enforcements were found from 2003, just outside the period when this country joined the EU and became subject to Directive 95/46. In sum, the DPA firstly ruled that the publication in a magazine of a photograph from a CCTV camera was using data for an unlawful purpose and secondly that a TV presenter had engaged in incorrect data processing by publishing during a show an identification document including a photo, identity code and the registration number of the document. See Latvia, Datu valst inspekcija, 2003.gada darba rezultāti (2003), pp. 19-20 (http://www.dvi.gov.lv/lv/wp-content/uploads/inspekcija/gada-parskati/2003.pdf).

${ }^{65}$ This may be linked a reality that "processes for resolving privacy complaints are often carried out in private to promote conciliation and efficient dispute resolution" (International Conference of Data Protection and Privacy Commissioners, Resolution on Case Reporting (2009)).
} 
addition, only provided lists of information for the past few years ${ }^{66}$ as opposed to for the period since the transposition of Directive 95/46 into national law. Turning to the DPAs which provided non-standard responses, evidence of enforcement was found on the Bulgarian and UK but not on the Czech, Luxembourg or Maltese DPA websites. Finally, as regards the websites of the national DPAs who were not questionnaire participants, some evidence of enforcement within the relevant period was readily found on the website of the Spanish and Icelandic DPAs but not on that of the Croatian, Danish, Norwegian or Romanian sites. These DPA-specific results are reported in binary form in the appendix to this article.

Moving to a more detailed examination of the DPA website data, in some contrast to the DPA questionnaire data, no support was found for the hypothesis that DPAs systematically prioritized enforcement action vis-à-vis material obtained without authorization from another controller compared to material obtained or generated in another fashion. ${ }^{67}$ In other respects, however, it was clear that DPA enforcement action was generally focused on what might be considered particularly serious violations of the data protection scheme. To begin with, no evidence of enforcement was found as regards very detailed and specific obligations of data protection such as the registration of data with the DPA or even subject access. For the reasons given above, however, care should be taken before equating this to a complete absence of activity here. To the contrary, material from the UK (albeit not on the UK DPA's own website) was uncovered demonstrating that at least

\footnotetext{
${ }^{66}$ For such an example see Estonia, Eesti Andmekaitse Inspecktsioon, Ettekirjutused (http://www.aki.ee/et/menetluspraktika/ettekirjutused).

${ }^{67}$ In fact, evidence of enforcement action which could clearly be characterized as involving the processing of information obtained without authorization was only found on six DPA websites (two of which provided nonstandard response to the survey). In contrast, evidence of action which appeared to relate to other types of information was found on eight DPA websites (one of which had provided a non-standard response to the survey). The attempt to place the examples in one or other of these categories did, however, indicate that this was by no means a simple task especially given the very limited information often disclosed in the published material.
} 
one photojournalist had been prosecuted for non-registration with the UK DPA. ${ }^{68}$ Nevertheless, the lack of publicity given to such matters on DPA websites does at least indicate that such actions are not a regulatory priority. Turning to the matters related to the accuracy of information, in 2003 the Icelandic DPA did censor a newspaper for stating that an individual murdered ${ }^{69}$ some fourteen years previously (who was not named but in the context was identifiable) had engaged in sexual activity prior to the murder despite the fact that evidence of this was dismissed in the court case at the time. ${ }^{70}$ A Greek example of enforcement action (case 38/2005) was also found concerning a misleading television broadcast of information related to a letter the complainant had written to a municipality asking that brothels lawfully in an area be allowed also to purchase or rent property in this area. In sum, the broadcast was censored as misleading as it failed to include the complainant's explanation for this letter. ${ }^{71}$ However, in both of these examples additional 'aggravating' circumstances were present, notably the illegitimacy of the collection of the underlying personal data in the Greek case and the presence of sensitive personal data ${ }^{72}$ in both cases. A range of other Greek regulatory decisions adverse to the media, which variously involved either ordinary members of the public (as in case of 38/2005) or individuals playing a more public role, also involved sensitive data processing. As regards

\footnotetext{
${ }^{68}$ McNally, Paul, 'Freelancers threatened with data protection fine', Press Gazette, 8 August 2008 (http://www.pressgazette.co.uk/node/41852).

${ }^{69}$ Unlike in a number of other Member States, in Iceland data relating to the deceased remains protected as personal data. See Iceland, Act on the Protection of Privacy as regards the Processing of Personal Data, art 2 (1).

${ }^{70}$ Iceland, Persónvernd, Ársskýrsla Persónuverndar 2003 (http://www.personuvernd.is/utgefidefni/arsskyrslur/2003/). Interestingly, three years later, and also in response to a complaint against the same newspaper, the authority changed tack and held that it had no authority to rule on journalistic matters. See Iceland, Persónvernd, Persónuvernd Ársskýrsla 2006, pp. 45-7 (http://www.personuvernd.is/media/frettir/arsskyrsla2006.pdf).

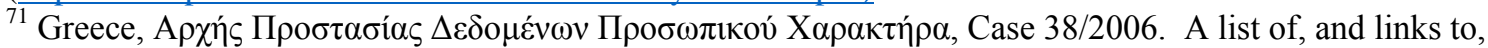

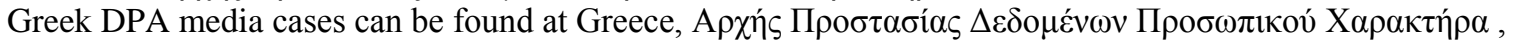

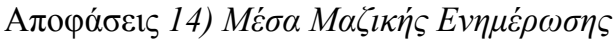
(http://www.dpa.gr/portal/page?_pageid=33\%2C15453\&_dad=portal\&_schema=PORTAL\&_piref33_15473_33 15453 15453.etos=-

1\&_piref33 15473 33 15453 15453.arithmosApofasis=\&_piref33 $15473 \quad 33 \quad 15453$ 15453.thematikiEnotita =187\& piref33 15473 33 15453 15453.ananeosi $=\%$ CE\% $\% 1 \%$ CE\%BD\%CE\%B1\%CE\%BD\%CE\%AD\%CF\% $89 \%$ CF\% $83 \%$ CE $\%$ B 7 ).

${ }^{72}$ Directive 95/46, art 8.
} 
the former, cases 140/2012 involved in part the publication of mental health information, whilst case $165 / 2012$ related to the publication of criminal suspicions or allegations. As regards the latter, cases 100/2000 and 73/2005 concerned the sexual data of a singer and designer (presented in the context of a journalistic inquiry into paedophilia) and the unlawful obtaining and broadcast of the erotic involvements of a bishop with an unknown person respectively. Other than in case 38/2005, fines were issued or upheld in all these cases and in cases 100/2000, 38/2005 and 165/2012 orders were also made variously to destroy the information, prohibit its broadcast or ensure anonymization. Although rejecting other elements of her complaint, the Bulgarian DPA censured a newspaper for publishing the religious identity of a person who had left her family in order to join a sect, attempting at the same time to sell her father's flat (in which she was living). ${ }^{73}$ It also ruled against and fined a newspaper for publishing in full an official psychiatric assessment of an individual against whom the editor of the newspaper was involved as defendant in a criminal case. No public interest was found in the published material. ${ }^{74}$ Meanwhile, in Italy the DPA issued a ruling against a television programme for its collection of drug test samples from fifty MPs ${ }^{75}$ the Netherlands DPA took action against a television production company (Eyeworks) for filming patients within Amsterdam's Free University Hospital using thirty-five installed cameras without having obtained prior, sufficiently specific and freely given consent ${ }^{76}$ and the Slovenian DPA criminally fined both the newspaper and the individual publisher for

\footnotetext{
${ }^{73}$ Bulgaria, Комисия за защита на личните данни, РЕШЕНИЕ № 14/19.03.2009 r. (http://www.cpdp.bg/index.php?p=element_view\&aid=145).

${ }^{74}$ Bulgaria, Комисия за защита на личните данни, , РЕШЕНИЕ № 69/23.01.2008 r. (https://www.cpdp.bg/index.php?p=element_view\&aid=105).

${ }^{75}$ Italy Garante per la protezione dei dati personali , Annual Report for 2006 - Summary (http://www.garanteprivacy.it/web/guest/home/docweb/-/docweb-display/docweb/1750262).

${ }^{76}$ Netherlands Autoriteit Persoonsgegevens , Preface to Annual Report 2012 (http://www.dutchdpa.nl/downloads_jv/annual_report_2012_preface.pdf).
} 
publishing an autopsy report concerning three victims who died at the entrance to a discotheque. $^{77}$

DPAs have also acted to protect categories of information which, although not technically sensitive, may raise similarly specific privacy concerns. For example, the Italian DPA 'prohibited the continued dissemination of images of the victim of a murder case that took place in Perugia, after those images had been broadcast by local TVs in utter contempt for human dignity'. ${ }^{78}$ Drawing on the inviolability of a person's home, it also banned the publication of pictures of the inside of (then Prime Minister) Silvio Berlusconi's villa taken using 'zoom lenses and intrusive, highly sophisticated systems'. ${ }^{79}$ Similarly related to a person's domicile, the Cypriot DPA issued a fine against the publication of a photo showing the names of occupants of a residential building. ${ }^{80}$ More generally, in Slovenia the DPA imposed a sanction on both the newspaper and the editor for the publication of unspecified personal information of a non-public figure included in a court judgment stressing that '[p]ublic interest, with regard to the provision or publication of information which merely satisfies curiosity, cannot in itself be the justification for an encroachment into the information privacy and/or constitutional right to the protection of personal data of an individual who is not in the public eye' ${ }^{81}$ Another aspect, brought into focus even more clearly in the cases below, relates to the protection of information, such as personal

\footnotetext{
${ }^{77}$ Slovenia, Informacijski pooblaščenec, Decision 0613-1/2006-22 (https://www.ip-rs.si/index.php?id=379). Similarly to Iceland (see note 70) and Italy (see note 78), in Slovenia data relating to the deceased continues to be regulated under data protection. See Slovenia, Personal Data Protection Act, art 23.

${ }^{78}$ Italian Garante per la protezione dei dati personali , Introduction to Annual Report 2008-09 (http://www.garanteprivacy.it/web/guest/home/docweb/-/docweb-display/docweb/1630962).. This case would appear to relate to the death of Meredith Kirchner. Similarly to Iceland (see note 70) and Slovenia (see note 77) data concerning the deceased falls within the scope of Italian data protection. See Italy, Personal Data Protection Code, sec 9 (3).

${ }^{79}$ Ibid.

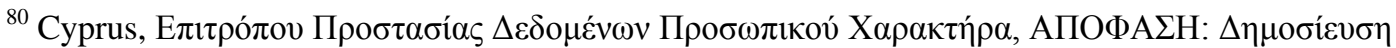

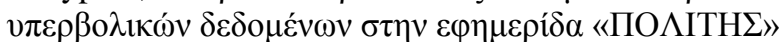
(http://www.dataprotection.gov.cy/dataprotection/dataprotection.nsf/All/878B2BB3BB9C507FC2257914003A2 7B9? OpenDocument).

${ }^{81}$ Slovenia, Informacijski pooblaščenec, Annual Report 2009, p. 31 (https://www.iprs.si/fileadmin/user_upload/Pdf/porocila/Annual-report-2009.pdf).
} 
identification numbers or clearly confidential personal details being held for discrete purposes by a non-journalistic organisation, which may require special protection due to their particularly strong relationship with the good functioning of social and economic life. Thus, the Slovenian DPA censured a broadcaster for including in its news coverage of a criminal complaint against three persons not only their names and dates of births but also their unique personal identification numbers; a newspaper publication of a similar criminal complaint detailing in this case the individual's name, date and place of birth, address, citizenship and unique personal identification number; the reproduction on a newspaper and commercial television website of an identification card belonging to a person against whom an arrest warrant had been issued and a newspaper photo of the passport of an individual suspected of a criminal offence. In all these cases, it was stated that the action taken secured the removal of the material. ${ }^{82}$ Somewhat similarly, the Lithuanian Inspector of Journalism Ethics fined a newspaper for publishing the personal identification and social security number of the AntiCorruption Chairman and Interim Mayor of Palanga. ${ }^{83}$ The Bulgarian DPA fined a newspaper for the unintentional inclusion of the personal identification numbers (and also names) of shareholders in a company being discussed within the newspaper. ${ }^{84}$ Meanwhile, the Italian DPA issued a general decision seeking to limit the journalistic publication of (often highly intimate) information contained in judicially ordered wiretap evidence held by the courts. This decision '[e]mphasised requirements for information materiality, respect for human dignity and special protection re: sex life'. ${ }^{85}$ Finally, the UK DPA's Operation Motorman investigation uncovered 'an unlawful trade in confidential personal information'

\footnotetext{
${ }^{82}$ Slovenia, Informacijski pooblaščenec, Annual Report 2007, pp. 32-33 (https://www.iprs.si/fileadmin/user_upload/Pdf/porocila/Letno-porocilo-07-ang.pdf).

${ }^{83}$ Lithuania, Žurnalistų etikos inspektorè, Surašytas administracinis nurodymas laikraščio "Palangos tiltas" redaktoriui-direktoriui (http://www.lrs.1t/intl/zeit.show?theme=781\&lang=1\&doc=3133) (accessed 04/06/2014).

${ }^{84}$ Bulgaria, Комисия за защита на личните данни, РЕШЕНИЕ № 551/11 r. (https://www.cpdp.bg/index.php?p=element_view\&aid=503).

${ }^{85}$ Italy, Garante per la protezione dei dati personali , Annual Report for 2006 - Summary (http://www.garanteprivacy.it/web/guest/home/docweb/-/docweb-display/docweb/1750262).
} 
involving UK journalists seeking a range of private details including 'current address, details of car ownership, an ex-directory telephone number or record of calls made, bank account details or [even] intimate health records'. ${ }^{86}$ Although this DPA did not launch legal action either against the media organizations or individual journalists, it did call on the Press Complaints Commission, then the body for the self-regulation of the press in the UK, to 'take a much stronger line to tackle press involvement in this illegal trade' and stated that it would 'not hesitate to prosecute journalists identified in previous investigations who continue to commit these offences' ${ }^{87}$ As regards each media publication, it also subsequently issued a breakdown of the number of such transactions it had positively identified and the number of journalists/clients using such services. ${ }^{88}$

It is also clear that some DPA enforcement actions have privileged the protection of an individual's photographic image as opposed to mere text providing comparable information. This aspect is clearest in the case of the Hungarian DPA which in 2007 held that the media were prohibited from publishing the photographs of police officers even if these revealed illegality or the misuse of police powers. ${ }^{89}$ In a new case in 2010 , however, the Hungarian DPA clarified that a photo revealing misuse, abuse or illegality could exceptionally be published where the freedom of the press interest was obviously more pressing than the right to personal data protection. ${ }^{90}$ A less controversial case involving children, another category which has garnered a degree of specific DPA attention, concerned

\footnotetext{
${ }^{86}$ UK, Information Commissioner's Office, What Privacy Privacy? (2006), p. 5 (see note 54). It later became clear that the obtaining especially of ex-directory mobile telephone numbers (which often had not had their security codes changed from the manufacturer's published default) was linked to media hacking into individual's voicemail systems. This prompted the UK Government to set up the Leveson Inquiry in 2011 which duly reported in late 2012. See United Kingdom, Leveson Inquiry, An Inquiry into the Culture, Practices and Ethics of the Press: Report (London: The Stationary Office, 2012), p. 673.

${ }^{87}$ Ibid, p. 6.

${ }^{88}$ UK, Information Commissioner's Office, What Price Privacy Now? (2006), p. 9 (https://ico.org.uk/media/about-the-ico/documents/1042392/what-price-privacy-now.pdf).

${ }^{89}$ Hungary, Nemzeti Adatvédelmi és Információszabadság Hatóság, Az Adatvédelmi biztos beszámolója 2007, pp. 137-138 (Case 1848/K/2007) (http://www.naih.hu/files/Adatvedelmi-biztos-beszamoloja-2007.PDF).

${ }^{90}$ Hungary, Nemzeti Adatvédelmi és Információszabadság Hatóság, Beszámoló az adatvédelmi bistos 2010. évi tevékenységéröl, pp. 150-151 (http://www.naih.hu/files/Adatvedelmi-biztos-beszamoloja-2010.PDF).
} 
a finding by the Irish DPA that the now defunct News of the World acted illegally by publishing the images of awell-known individual together with their child whilst shopping, at the same time identifying the child by name and age and referring to a third party's perception of how they were getting along. ${ }^{91}$ A case was also located in Spain where the federal DPA issued a fine (upheld in subsequent court action) against a newspaper which, without the consent of those involved, had installed a webcam within its newsroom which took an image every fifteen seconds which was then made available on the newspaper's website. $^{92}$ Finally, it is clear that in many of the cases considered above, the DPA was clearly motivated to act not only because of the nature of the information itself but also the surreptitious, deceptive or otherwise potentially invidious means by which it had been obtained. Although examples of action concerning public figures were also found, it is clear that a number of DPAs have been more willing to take proactive steps to safeguard information related to ordinary members of the public.

\section{VI - General Analysis}

As previously noted, the journalism enforcement findings reported in this article are a subset of a broader project exploring the interface between European data protection and public freedom of expression in general. This project has gathered and analysed a wide range of related information including questionnaire data exploring both DPA's legal interpretative stance and their enforcement efforts in the area of 'new' internet media (from newspaper archives to social networking to street mapping services) as well as the financial resources

\footnotetext{
${ }^{91}$ Ireland, Data Protection Commissioner, Case Study 6 of 2006: News of the World: Limits of the Media Exemption

(http://www.dataprotection.ie/ViewDoc.asp?fn=\%2Fdocuments\%2Fcasestudies\%2FCategoryCS\%2Ehtm\&CatI $\mathrm{D}=10 \& \mathrm{~m}=\mathrm{c})$.

${ }^{92}$ Sentencia De la Audiencia Nacional de 24-01.2003. Sala de lo contenciosoadministrativo. Sección primera. Tratamiento de datos de carácter personal a través de imágenes captadas por una webcam y su transmisión a través de Internet (https://www.agpd.es/portalwebAGPD/canaldocumentacion/sentencias/common/SentenciaDe-la-Audiencia-Nacional-de24.pdf).
} 
they have available for their data protection activities. An systematic coding of the local statutory data protection applicable to journalism as well as an analysis of DPA interpretation of the same has also been completed. Although these parts of the project have been written up in detail elsewhere, ${ }^{93}$ this material will be drawn upon here so far as relevant.

Turning first to consider the proportion of standard DPA questionnaire responses which reported at least some enforcement as regards journalism, this figure was in fact higher than the reported level of enforcement against any of the seven 'new' media inquired about and significantly higher than the average level of enforcement $(43 \%)$ reported there (see Chart Three below). ${ }^{94}$ This comparative result is particularly surprising given that, as noted in section one, $\operatorname{six}^{95}$ of the standard responses vis-à-vis journalism were received from DPAs where local statute did not provide for any regulatory oversight over data protection in the area of special expressive purposes such as journalism, whilst in two ${ }^{96}$ others default regulatory powers were specially limited (and in one case made exercisable by a specialist media body) in this special area. ${ }^{97}$ If at least those cases where no direct regulatory competence over journalism exists are excluded from the results, then the proportion of those DPAs reporting some enforcement efforts rises to $62 \%(n=21){ }^{98}$ This apparent relative emphasis on professional journalism as opposed to 'new' internet media may be at least

\footnotetext{
${ }^{93}$ Erdos, supra notes $10,11,12$ and 13.

${ }^{94}$ Please note that all five DPAs (Bulgaria, Czech Republic, Luxembourg, Malta and UK) which only provided non-standard answers to the professional journalism enforcement part of the survey provided a standard response to the 'new' internet media enforcement questions. In contrast, the German Federal DPA did not do so. As a result, the sample size (n) is slightly different. This difference, however, does not impact on the overall thrust of these results. For a complete analysis of the 'new' internet media results see Erdos supra note 13.

${ }^{95}$ Namely, the Austrian, German Federal, the German Brandenberg, the German Mecklenberg-Vorpommern, the German Rhineland and the Netherlands DPA.

${ }^{96}$ Namely, the German Schlewig-Holstein and the Lithuanian DPAs (the latter coupled with the transfer to responsibility to the Lithuanian Inspector of Journalism Ethics). The Spain Catalan DPA, which provided a standard response in both sections of the survey, also has limited powers here but this is due to the federal distribution of power rather than due to concerns specific to special expression.

${ }^{97}$ In contrast, with the exception of newspaper archiving and to a certain extent individual blogging, the DPAs surveyed very clearly rejected the proposition that special expressive purpose derogations were applicable vis-àvis 'new' internet media. Again, for a full analysis of this issue see Erdos, supra note 13.

${ }^{98}$ Meanwhile, responses from DPA's whose powers of otherwise especially restricted are also similarly excluded then the figure becomes $63 \%(n=19)$.
} 
partially linked to the fact that, whilst journalism has long been recognised to be a highimpact activity which may seriously impact on individual privacy and related rights, ${ }^{99}$ it is only fairly recently that 'new' internet media publication has assumed a similar salience. It may also reflect challenges in deploying nationally-situated regulatory tools in relation to 'new' internet media organisational actors, many of whom are radically transnational in nature.

\section{Chart Three: Reported DPA enforcement against professional journalism compared with actors operating in the 'new' media area}

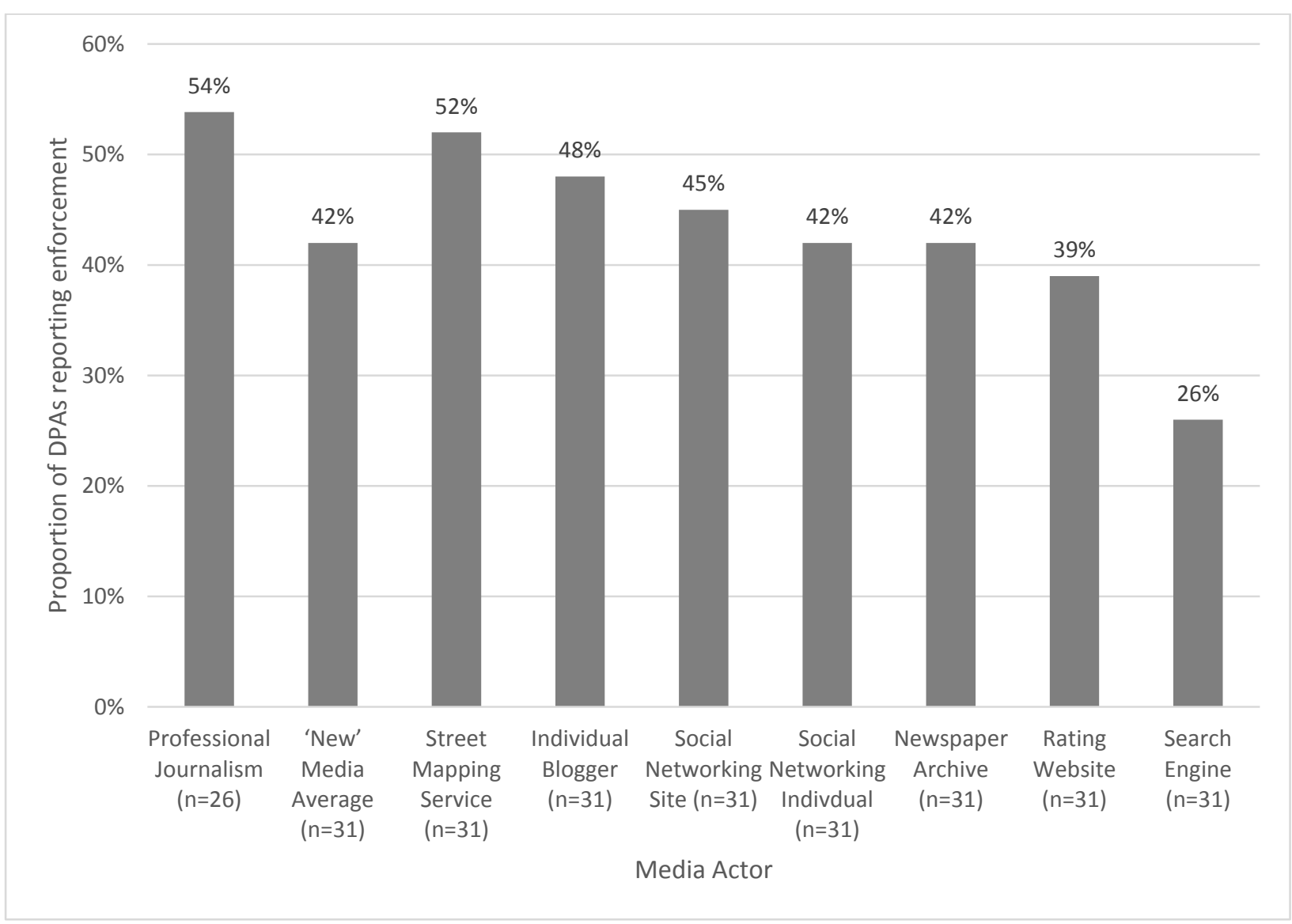

When analyzed in absolute terms, however, the enforcement figures reported by DPAs within the journalistic sector appear low. Journalism constitutes a clear exercise of the fundamental right to freedom of expression and often serves the public good. Nevertheless,

\footnotetext{
${ }^{99}$ Indeed, such a recognition may be traced back at least to the late nineteenth century. See, in particular, Samuel Warren and Louis Brandeis, 'The Right to Privacy', Harvard Law Review (pp. 193-220) (1890).
} 
as a result of its mass reach and sometimes intrusive nature, it not only has very significant "power to damage citizen's lives" 100 but the exercise of this power may on occasion be clearly unwarranted. Given data protection's central safeguarding mission, we might therefore reasonably expect that all DPAs with regulatory powers in this area would have engaged in at least some enforcement action since the coming into force of Directive 95/46. This has clearly not been the case.

The gap between the stringent safeguarding standards set down even as regards journalism in the formal statutory data protection law of most EEA states and the much more limited track-record of many DPAs is made even more apparent when the detail of the reported enforcement is examined. Thus, the very low level of enforcement indicated as regards specific aspects of data protection contrasts markedly with the often peremptory standards which are set down in local data protection law here. ${ }^{101}$ For example, whilst only five $^{102}(19 \%)$ standard DPA responses reported enforcement as regards subject access, statutory law in eight $(31 \%)$ of these jurisdictions ${ }^{103}$ subject all journalistic data to full compliance with this provision (with the exception, in two ${ }^{104}$ cases, of data on sources), whilst only five ${ }^{105}(19 \%)$ jurisdictions grant the media an absolute exemption here. Even more strikingly, whilst only four ${ }^{106}(15 \%)$ standard DPA responses indicated action to ensure rectification of inaccurate data, statutory law in no less than fifteen ${ }^{107}(58 \%)$ of these jurisdictions subject the media to compliance with the accuracy requirement of data

\footnotetext{
${ }^{100}$ Grant, Hugh, 'Introduction' in Brian Cathcart, Everybody's Hacked Off: Why we don't have the Press we deserve and what to do about it, London: Penguin (2012), p. viii.

${ }^{101}$ For a comprehensive elucidation of the statutory data protection law applicable to journalism in each EEA state (including references to all applicable legislation) see Erdos, supra note 10.

102 These were from Estonia, Hungary, Ireland, Italy and Slovenia.

${ }^{103}$ Namely, Cyprus, Greece, Hungary, Italy, Latvia, Slovakia, Slovenia and Spain Catalonia. In all of these jurisdictions bar Spain Catalonia, DPA regulatory competence to enforce is also statutorily untrammelled. ${ }^{104}$ Namely, Hungary and Italy.

${ }^{105}$ Namely, Austria, Finland, Lithuania, the Netherlands and Sweden.

106 These were from Belgium, Hungary, Italy and Latvia.

${ }^{107}$ Namely, Belgium, Cyprus, Estonia, France, Greece, Hungary, Latvia, Liechtenstein, Lithuania, Luxembourg, the Netherlands, Portugal, Slovakia, Slovenia and Spain Catalonia. In all of these jurisdictions bar Lithuania, the Netherlands and Spain Catalonia, regulatory competence is also statutorily untrammelled.
} 
protection in full, whilst only two ${ }^{108}(8 \%)$ jurisdictions grant journalism an unqualified exemption. Finally, although only one ${ }^{109}(4 \%)$ standard DPA response reported enforcement of the duty to register/notify with the DPA, statutory law in seven (27\%) of these jurisdictions ${ }^{110}$ also stipulates that the media must comply in full with this requirement. ${ }^{111}$ The DPA website review reported in section three found even less evidence of enforcement of specific aspects of data protection here. Some of the more generalized enforcement, such as the Hungarian DPA's restrictions on photography, did appear both far-reaching and disproportionately burdensome on the exercise of free expression rights. However, most of the DPA enforcements were targeted towards protecting quite specific types of information including sensitive and related categories of data and information whose confidentiality may be considered critical to the functioning of social and economic life.

The relatively limited extent of DPA enforcement here may be linked to severe tension between the often stringent standards set down even for journalism in local statutory data protection law and the media's right to freedom of expression which is protected in human rights instruments at both pan-European and national level. For example, statutory data protection law in seven $(27 \%)$ of the DPA jurisdictions which provided a standard response to the questions on enforcement prohibit the gathering of 'sensitive' personal data at least without waiver ${ }^{112}$ by the data subject even if, for example, this concerns the political opinions of an influential public figure. ${ }^{113}$ These kind of restrictions clearly run counter to a pan-European commitment to strictly police the proportionality of any limit on the use and

\footnotetext{
${ }^{108}$ Namely, Finland and Sweden. In both these cases DPA competence over journalism is also absent (see note 134).

${ }^{109}$ Namely, Liechtenstein.

${ }^{110}$ Namely, Belgium, Cyprus, Estonia, Greece, Portugal, Slovakia and Spain Catalonia.

${ }^{111}$ In this case, a larger grouping of $15(58 \%)$ of jurisdictions do grant institutional journalism an absolute exemption here. These are Austria, Finland, the German federal DPA jurisdiction as well as the four German Länder jurisdictions falling within the survey, Hungary, Ireland, Italy, Lithuania, Luxembourg, the Netherlands, Slovenia and Sweden (Erdos, supra note 10, p. 172).

${ }^{112}$ Either through the obtaining of explicit consent or through that individual manifestly making public the information. See Directive 95/46, art. 8 (2)(a) and 8 (2)(e).

${ }^{113}$ These jurisdictions are Hungary, Liechtenstein, Lithuania, Slovakia, Slovenia, Spanish Catalonia and Portugal.
} 
flow of information which is 'capable of discouraging open discussion of matters of public concern'. ${ }^{114}$ The need to reconcile journalistic freedom with data protection, if necessary irrespective of specific statutory prohibitions set out by the latter, is at least implicitly accepted by most if not all EEA DPAs. For example, in the DPA survey explored in this article, regulators were also asked to interpret the legality of a hypothetical example of undercover political journalism. Notwithstanding its formal statutory prohibition in the seven jurisdictions as mentioned, not one DPA held that the activity was ipso facto illegal. ${ }^{115}$

Irrespective of its general validity, however, the tension between data protection and freedom of expression is still unable to explain critical aspects of the enforcement patterns elucidated here. Thus, the data on enforcement discloses very low levels of activity even as regards the policing of standards which have manifest importance, are widely recognized in local data protection laws and present only a limited and generally justifiable interference with freedom of expression. A clear example relates to the duty to take care not to publish significantly inaccurate personal information. Not only can inaccurate reporting by the media cause individuals considerable distress, but a commitment to accuracy has been understood to constitute 'the foundation on which journalism depends'. ${ }^{116}$ Given this, the UK DPA was right to recently acknowledge that it is 'hard to argue that it is in the public interest to publish clearly inaccurate stories or to retain clearly inaccurate information without making reasonable checks'. ${ }^{117}$ Secondly, even where the tension between data protection and media expression is arguably much more severe, DPAs often adopt interpretations of the law which would still impose strict requirements on journalists. For example, the EEA DPA survey found that ten $(38 \%)$ of the regulators which provided a standard response to the questions on

\footnotetext{
114 Thorgeirson $v$ Iceland (1992) 14 EHRR 843 at [68].

${ }^{115}$ For a full write-up of this example see Erdos, supra note 11, pp. 639-643 and 645-646.

${ }^{116}$ United Kingdom, Leveson Inquiry, note 86, p. 673.

${ }^{117}$ UK, Information Commissioner's Office, Data Protection and Journalism: A Guide for the Media (2013) (https://ico.org.uk/media/for-organisations/documents/1552/data-protection-and-journalism-mediaguidance.pdf).
} 
enforcement held that, as a matter of interpretation, professional journalism had a duty to comply in full with the right to subject access (excepting only information revealing sources), ${ }^{118}$ whilst only five ${ }^{119}(19 \%)$ held that journalism should be entirely exempted from this. ${ }^{120}$ However, these interpretative perspectives clearly sit uneasily with the fact, as noted above, only five $\mathrm{e}^{121}(19 \%)$ regulators actually reported ever having undertaken enforcement here.

It may also be argued that these low levels of enforcement are linked to the presence of alternative accountability mechanisms within the journalistic sector. It is certainly true that a variety of these systems, often based largely on self-policing, do exist. ${ }^{122}$ Nevertheless, coverage not only remains very patchy ${ }^{123}$ but their efficacy in securing responsible behaviour by the media remains rather doubtful. Thus, in 2012 the UK Leveson Inquiry found that 'time and time again, there have been serious and uncorrected failures within parts of the national press that may have stretched from the criminal to the indefensibly unethical, from passing off fiction as fact to paying lip service to accuracy', ${ }^{124}$ ultimately holding that '[i]t is difficult to avoid the conclusion that the self-regulatory system was run for the benefit of the press not of the public'. ${ }^{25}$ Even in Denmark, which has adopted a significantly more legalized form of general media accountability, Fielden notes that also in 2012 the Danish Parliamentary Committee on Legal Affairs highlighted 'recent egregious errors in the Danish press - including a nursery manager wrongly accused of complicity in paedophile abuse, and a man wrongly branded a killer', at the same time

\footnotetext{
${ }^{118}$ Namely, the Belgium, Estonian, German Schlewig-Holstein, Gibraltan, Greek, Italian, Maltese, Slovakian, Slovenian and Cypriot DPAs (the latter in principle not even accepting the caveat as regards source information).

${ }^{119}$ Namely, the Austrian, Finnish, French, German Rhineland-Palatinate and Swedish DPAs.

${ }^{120}$ See Erdos, supra note 11, p. 645.

${ }^{121}$ Namely, the Estonian, Hungarian, Irish, Italian and Slovenian DPAs.

${ }^{122}$ See Eberwein, Tobias, Susanne Fengler, Epp Lauk and Tanja Leppik-Bork (eds.), Mapping Media Accountability - in Europe and Beyond (Verlag, 2011) and Fielden, Lara, Regulating the Press: A Comparative Study of International Press Councils (Reuters Institute, 2012).

${ }^{123}$ Ibid.

${ }^{124}$ UK Leveson Inquiry, note 86, p. 739.

${ }^{125}$ Ibid, p. 1579.
} 
finding that 'newspapers [were] doing their best to bury publication of Press Council decisions with as little prominence as possible'. ${ }^{126}$ Finally, given the ubiquitous nature of personal information processing, DPAs necessarily exercise their regulatory role within many other sectors, such as consumer credit and direct marketing, which have developed often very extensive self-regulatory or even State-centric accountability mechanisms. ${ }^{127}$ At the very least, therefore, the journalistic sector does not appear at all unique in this regard.

A final potential factor behind this low enforcement may be that DPAs are simply finding themselves overwhelmed by myriad demands in a context not only of exponential increases in the number and range of actors carrying out significant personal data processing but also by very limited regulatory resources. The DPA questionnaire sought to probe this possibility by asking each regulator to specify their annual data protection budget. ${ }^{128}$ Given the special division of responsibilities between the federal and local DPAs in Germany and Spain, it was decided best to combine the figures supplied by the four German Länder DPAs with that of the Federal DPA pro-rated on the basis of each Land's population size, in the process dropping any separate analysis of the Federal DPA itself. Since the Federal DPA had indicated, and the DPA website review confirmed, that it had not engaged in enforcement activity here, data on both national and regional DPA enforcement against the media in each Land could also effectively be combined. As regards Spain, in light of the absence of any response from the federal DPA it was felt best to simply drop the Spain Catalan DPA from

\footnotetext{
${ }^{126}$ Fielden, Lara, Regulating the Press: A Comparative Study of International Press Councils, International Forum for Responsible Media Blog (3 May 20112) (https://inforrm.wordpress.com/2012/05/03/regulating-thepress-a-comparative-study-of-international-press-councils-lara-fielden/). Whilst the Danish Press Council does, as detailed above at note 41 , have limited responsibilities to police data protection law vis-à-vis the media, its responsibilities are principally established under the Media Liability Act 1998.

${ }^{127}$ See Bennett, Colin J. and Charles D. Raab, The Governance of Privacy: Privacy Instruments in Global Perspective (MIT Press, 1997), passim and especially p. 155 and 157.

${ }^{128}$ Where, as is regularly the case, part of the DPA was used for other purposes, such as Freedom of Information, DPAs were asked to estimate that part of their budget allocated to data protection.
} 
this part of the analysis. ${ }^{129}$ All of the gross DPA jurisdiction figures were then translated into per capita ones. ${ }^{130}$ These results indicated that that the gross reported DPA jurisdictional budget was approximately $€ 3.4 \mathrm{M}$ and the median per capita budget $€ 0.33$. Whilst it is clearly difficult to elaborate precisely what a DPA's budget should be, these figures hardly seem commensurate with the task of ensuring effective and comprehensive regulation of both the public and private sectors in a world where 'our lives are now becoming a continuous exchange of information'. ${ }^{131}$ Such a conclusion chimes with the EU Agency for Fundamental Rights' analysis which found that '[a]t the functional level understaffing and the lack of adequate financial resources among several supervisory bodies constitutes a significant problem. In many Member States, DPAs are not in a position to carry out the entirety of their tasks because of the limited economic and human resources available to them'. ${ }^{132}$

Whilst regulatory enforcement of data protection in the journalistic sphere has generally been limited, it is also clear that its extent has varied considerably between the different DPAs. Given this, a final empirical issue to explore is what might help explain these differences. This will be the task of the next section of the article..

\section{VIII - Explaining Divergences in the Extent of DPA's Enforcement Activity}

There are two potential drivers of the divergence in DPAs' enforcement activity in the journalistic sector which this article can usefully explore. Firstly, notwithstanding the

\footnotetext{
${ }^{129}$ For completeness, the Spanish Catalan DPA reported a budget of approximately $€ 2.8$ million, whilst the German Federal DPA reported one of $€ 8.5$ million.

${ }^{130}$ For a complete analysis of the rationale for these decisions as well as an elaboration for precisely how the calculations were performed see Erdos, supra note 12.

${ }^{131}$ EU, Agency for Fundamental Rights, Data Protection in the European Union: The Role of National data Protection Authorities (2010), p. 6 (http://fra.europa.eu/sites/default/files/fra uploads/815-Dataprotection_en.pdf).

${ }^{132}$ Ibid, p. 6.
} 
substantial general gap between statutory law and enforcement realities, greater stringency in statutory data protection in the area of journalism may lead to more extensive DPA enforcement here. Secondly, better resourcing of DPAs may result in more extensive enforcement including in the journalistic sector.

Turning first to consider the role of statutory law, this article draws upon a systematic analysis by the author of the extent to which the statutory laws of each DPA jurisdiction continued to apply EU data protection standards even in the journalistic sector. ${ }^{133}$ In sum, based on an analysis of the application of all eighteen core EU data standards, jurisdictions were placed on a 0 to 1 scale where 0 represented the complete disapplication of these standards in the journalistic sphere and 1 represented their full application even within this sensitive area. This resulted in a detailed index of the formal legal strength of substantive data protection safeguards within this sector. One aspect which this study did not, however, explore was whether, at a procedural level, the formal powers of DPAs to intervene within the purely journalistic area had been retained, restricted or removed entirely. However, given this article's focus is on DPA enforcement, this aspect may also be considered relevant. Therefore, alongside the existing index of the substantive stringency of statutory data protection, a new measure was created which factored in the presence and strength of DPA enforcement powers here. In sum, seven DPA jurisdictions (19\%) were assigned a procedural power value of 0 since DPA powers in the purely journalistic sphere had been entirely removed by statute, ${ }^{134}$ seven DPA jurisdictions (19\%) were assigned a value of 0.5

\footnotetext{
${ }^{133}$ See Erdos, supra note 10. Please note that the unit of analysis in this article was Member State jurisdiction (together with the special case of Gibraltar which effectively operates as a separate State for these purposes). In contrast, the unit of analysis here is sub-divided into regional DPA geographical jurisdictions where relevant. In addition, a small downward adjustment (from 0.72 to 0.67 ) has been made to the figure for Estonia reflecting the fact that this jurisdiction's law does provide a public interest exemption to the right of subject access. See Estonia, Personal Data Protection Act, s. 12 (4). This was not reflected in the calculation of the original figure. ${ }^{134}$ Namely, as regards the survey participants, Austrian, Netherlands and all of the German DPAs other than that of Germany Schleswig-Holstein, together with the Norwegian and Icelandic national DPAs which did take part in the survey but whose legal frameworks were nevertheless analysed. See Austria, Federal Act Concerning the Protection of Personal Data (DSG), sec 48; Germany, Federal Data Protection Act, sec 41 (1); Germany,
} 
since their powers here had been curtailed (and in two cases made exercisable by a specialist media regulator $)^{135}$ rather than removed entirely, and twenty-three DPA jurisdictions $(62 \%)$ assigned a value of 1 since their powers were not limited in statutory data protection law here at all. ${ }^{136}$ This procedural power value was then multiplied by the value for the substantive stringency of data protection applicable to journalism in the jurisdiction in order to produce a combined index of both the substantive and procedural potency of regulatory data protection within each jurisdiction. As regards both the substantive and the combined substantive and procedural measures, Table One overleaf details a correlative analysis ${ }^{137}$ with, firstly, the extent of journalistic enforcement as reported in the DPA questionnaire (cf. Chart Two above) and, secondly, a binary value measuring whether material indicative of such enforcement was found in the DPA website review. As can be seen, irrespective of the general gap between the statutory law and DPA enforcement practices in the area of journalism, the evidence presented clearly shows that a jurisdiction with more stringent statutory provisions is far more likely to have engaged in (various types of) enforcement action here. Thus, there was a very strong positive correlation of 0.677 and 0.578 respectively between both the substantive and the combined substantive and procedural

Brandenberg, Pressegesetz des Landes Brandenburg, sec 16a and Staatsvertrag über die Zusammenarbeit zwischen Berlin und Brandenburg im Bereich der Medien, sec 36; Germany, Mecklenburg-Vorpommern, Landespressegesetz für das Land Mecklenburg-Vorpommern and Rundfunkgesetz für das Land MecklenburgVorpommern, sec 18a and Rundfunkgesetz für das Land Mecklenburg-Vorpommern;, sec 61; Germany, Rhineland Palatinate, Landesmediengesetz (LMG) Rheinland Pfalz, sec 12; Iceland, Act on the Protection of Privacy as regards the Processing of Personal Data, art 5; Netherlands, Personal Data Protection Act, art 3 (1); and Norway, Personal Data Act, sec 7.

${ }^{135}$ This value was assigned to the following DPA survey participants, Germany Schleswig Holstein, Lithuania (with transfer of powers to the Inspector of Journalist Ethics), Malta, Spain Catalonia (due in this case to federalism rather for the specific purpose of reducingscrutiny vis-à-vis journalism), Sweden and the UK, together also with the Denmark national DPA (with transfer of powers to the Danish Press Council) which did not participate in the survey. See Denmark, Compiled version of the Act on Processing of Personal Data, s. 2 and Lov om massemediers informationsdatabaser, kapitel 4; Germany, Gesetz über die Presse, sec 10 and Medienstaatsvertrag HSH, sec 37; Lithuania, Law on the Legal Protection of Personal Data, art 8; Malta, Data Protection Act, sec 6 (1)-(3); Spain, Catalonia, Ley 32/2010, de 1 de octubre, de la Autoridad Catalana de Protección de Datos, art 3; Sweden, Personal Data Act, sec 7; and United Kingdom, Data Protection Act, sec 4546.

${ }^{136}$ This value was assigned to all the other DPAs which participated in the survey, together with the Croatian, Romanian and Spanish national DPAs which did not.

${ }^{137}$ Given the clearly non-parametric nature of all this data, the Spearman's Rank correlative test was adopted. 
measure of the stringency of formal law and the more granular enforcement figures reported in the DPA survey. Both of these results were statistically significant at the $0.01 \%$ level (one-tailed test). Even as regards the more limited DPA website review measure, there were also clearly positive correlation figures of 0.252 and 0.186 respectively, the former of which also had statistical significance at the $0.1 \%$ level (one-tailed test). ${ }^{138}$

Table One: Spearman Rank Correlations (and One-Tailed Significance Tests) between DPA Questionnaire Enforcement Extent, DPA Website Review Enforcement Measure, Statutory Law and DPA Resourcing Measures

\begin{tabular}{|c|c|c|}
\hline & $\begin{array}{l}\text { DPA Questionnaire } \\
\text { Enforcement Extent }\end{array}$ & $\begin{array}{l}\text { DPA Website Enforcement } \\
\text { Measure }\end{array}$ \\
\hline \multicolumn{3}{|l|}{ Statutory Law } \\
\hline Substantive Measure & $\begin{array}{l}\text { Coefficient: } 0.677 * * * \\
\text { Significance: } 0.000 \\
\text { N: } 26\end{array}$ & $\begin{array}{l}\text { Coefficient: } 0.252^{*} \\
\text { Significance } 0.066 \\
\text { N: } 37\end{array}$ \\
\hline $\begin{array}{l}\text { Combined Substantive and } \\
\text { Procedural Measure }\end{array}$ & $\begin{array}{l}\text { Coefficient: } 0.578 * * * \\
\text { Significance: } 0.001 \\
\text { N: } 26\end{array}$ & $\begin{array}{l}\text { Coefficient: } 0.186 \\
\text { Significance: } 0.135 \\
\text { N: } 37\end{array}$ \\
\hline \multicolumn{3}{|l|}{ DPA Resourcing } \\
\hline Combined Budget Measure & $\begin{array}{l}\text { Coefficient: }-0.256 \\
\text { Significance: } 0.109 \\
\text { N: } 25\end{array}$ & $\begin{array}{l}\text { Coefficient: }-0.095 \\
\text { Significance: } 0.311 \\
\text { N: } 29\end{array}$ \\
\hline Gross Budget Measure & $\begin{array}{l}\text { Coefficient: }-0.265^{*} \\
\text { Significance: } 0.100 \\
\text { N: } 25\end{array}$ & $\begin{array}{l}\text { Coefficient: } 0.095 \\
\text { Significance: } 0.311 \\
\text { N: } 29\end{array}$ \\
\hline Per Capita Budget Measure & $\begin{array}{l}\text { Coefficient: }-0.316^{*} \\
\text { Significance: } 0.062 \\
\text { N: } 25\end{array}$ & $\begin{array}{l}\text { Coefficient: }-0.330 * * \\
\text { Significance: } 0.040 \\
\text { N: } 29\end{array}$ \\
\hline
\end{tabular}

Significant at the 0.01 level $(* * *) ; 0.05$ level $(* *)$ and 0.1 level $(*)$

\footnotetext{
${ }^{138}$ It may be argued that, given that study is exploring enforcement since the transposition of Directive 95/46, it might be appropriate to augment both these enforcement scores for those DPA jurisdictions within Eastern Europe as well as Cyprus and Malta since they only became members of the EU and subject to the Directive well after 24 October 1998 when transposition within the EU was generally required (art. 32.1, Directive 95/46). Such an augmentation can be achieved by adjusting these figures to reflect the fact that, whilst the study generally probed some 141/2 years of potential enforcement, Bulgaria only joined the EU on 1 May 2005 and therefore 'lost' approximately 8 years of potential enforcement (55\% of the total period), whilst the other jurisdictions joined on 1 May 2005 and therefore similarly 'lost' approximately $5 \frac{1}{2}$ years (38\% of the total period). Such an adjustment in fact strengthens the findings reported here. In sum, the correlations in question shift to $0.680 * * *$ (significant 0.000 ), $0.594 * * *$ (significance 0.001 ), $0.276 * *$ (significant 0.049 ) and $0.220 *$ (significance 0.096) respectively. As an EU-associated EEA state, Liechtenstein only technically became subject to the Directive on 26 June 1999 (see note 3). However, this seven-month gap was considered too small to have a significant effect on these results.
} 
Moving on to consider the potential impact of differences in resourcing, it may be hypothesized that the capacity of a DPA to engage in extensive enforcement may depend positively both on greater levels of overall funding and on greater levels of per capita finding. Thus, a small DPA, even if well-funded on a per capita (head of resident population) basis, may well experience difficulty in engaging with the often complex and specialized issues which enforcement in the journalistic sphere can raise. Similarly, a DPA with a comparatively large gross budget but minimal per capita resources may be so over-burdened in responding to the myriad of routine data protection concerns that it is similarly unable to intervene with the complex and specialised issues raised by the journalistic sector. On the other hand, it may also be argued that either only the regulator's gross or only its per capita levels of funding will in practice prove of significant. In order to test these hypotheses, a combined linear scale of both the gross and per capita measures also created to sit alongside the gross and per capita budget measures themselves. ${ }^{139}$ A Spearman's Rank Correlation was then performed on each of these variables and both the DPA survey enforcement extent figures and the DPA enforcement website findings. As can be seen in Table One above, the results here were very surprising. Firstly, a negative rather than positive correlation, albeit of only $-0.256,-0.265$ and -0.316 respectively, was revealed between the DPA survey enforcement extent and each of the DPA resourcing figures. Moreover, as regards both the per capita and gross budget measures, this result achieved one-tailed significance at the $0.1 \%$ level (albeit only barely so in the latter case). The correlations with the DPA enforcement website findings were more ambiguous. Effectively no correlation was revealed with either the combined or the gross budget measures. Conversely a correlation of -0.330 was found with the per capita measure which moreover attained one-tailed significance at the $0.05 \%$

\footnotetext{
${ }^{139}$ As noted previously, adjustments were made to reflect the federal nature of Germany and Spain. In the case of the German Länder a portion of the German Federal DPA budget was notionally reallocated to the German Land based on its population size within Germany. The German Federal DPA was then dropped from this part of the study. In the absence of a response from the Spanish Federal DPA, the Spanish Catalan DPA was also dropped.
} 
level. ${ }^{140}$ Although it is recognised that these budget figures focus on one period of time, whilst the enforcement figures relate to a longer period, these results indicate at the very least that better resourcing of DPAs (whether on a combined, gross orper capita basis) will not by itself lead to any more extensive regulatory enforcement being undertaken in the area of journalism. Interestingly, approximately the same result was found as regards DPA enforcement and resourcing in the area of 'new' media such as rating websites, social networking and search engines. This is despite the fact that, with the exception of newspaper archives, most DPAs hold that European data protection's special expressive purposes

provision ${ }^{141}$ will, unlike in the area of professional journalism, not be applicable here. ${ }^{142}$ This suggests that what might ultimately fuel enforcement in both contexts may be a DPA's own ideological willingness to intervene in what is likely to be an area of both complexity and controversy. Whilst strongly correlated with the stringency of formal statutory provisions regarding journalism, such an internal DPA stance would ultimately operate semiautonomously from this.

\section{VIII - The Future of Data Protection Regulation of Journalism within Europe}

After several years of negotiation, in April 2016 the EU agreed a new General Data Protection Regulation (GDPR) which will replace Directive 95/46 in May 2018. In general, the Regulation augments the existing commitment to a 'high level of protection of individuals ${ }^{143}$ across Europe with more stringent default rules set out especially as regards

\footnotetext{
${ }^{140}$ If the enforcement results for Eastern Europe together with Cyprus and Malta are augmented to account for the number of years when they did not fall under Directive 95/46 (see note 138), then these results generally become slightly starker. In sum, the correlations cited shift to $-0.353 * *$ (significance: 0.042 ), $-0.340 * *$ (significance 0.048$),-0.343 * *$ (significance 0.047 ), -0.199 (significance: 0.151 ), -0.011 (significance 0.477 ) and $-0.335 * *$ (significance 0.038 ).

${ }^{141}$ Directive 95/46, art 9.

${ }^{142}$ See Erdos, supra note 12, p. 541.

${ }^{143}$ Regulation 2016/679, Recital 10.
} 
ensuring information transparency for data subjects. ${ }^{144}$ There is also a much greater formal emphasis on enforcement and harmonization. Most notably, DPAs will be empowered to issue administrative fines for breaches of most aspects of the regime of up to either $€ 10 \mathrm{M}$ or $€ 20 \mathrm{M}$ or in the case of commercial undertakings up to either $2 \%$ or $4 \%$ of annual worldwide turnover if this is higher. ${ }^{145}$ It is further stipulated that each DPA ensures that fines 'in each individual case' are 'effective, proportionate and dissuasive" ${ }^{146}$ and that the Member States provide them with the 'resources, premises and infrastructure necessary for the effective performance of its tasks and exercise of its powers'. ${ }^{147}$ The Regulation will also replace the existing Article 29 Working Party with a new European Data Protection Board which will have greatly enhanced powers and responsibilities to ensure a harmonized approach across Europe in particular through administrating a new 'consistency mechanism' which ultimately can result in a binding pan-European decision being imposed on national and regional DPAs. ${ }^{148}$ Rather foreshadowing the Regulation, recent CJEU judgments such as Google Spain (2014) and Schrems (2015) have also recognised the importance of data protection within the European legal order, a development which reflects its status as a EU fundamental rights post-Lisbon.

Nevertheless, specifically as regards processing for 'journalistic purposes' a significant continuity of approach is apparent. Article 85(2) of the GDPR states that Member States shall provide for derogations from any of the GPDR's substantive and most of its procedural provisions (including the 'consistency mechanism' detailed above) here 'if they

\footnotetext{
${ }^{144}$ See especially arts 12 to 14 , Regulation 2016/679 compared to arts 10 and 11 of Directive 95/46. In some tension with this, and in contrast to Directive 95/46, recital 27 of the Regulation clarifies that it 'does not apply to the personal data of deceased persons'. However, the recital adds that 'Member States may provide for rules regarding the processing of personal data of deceased persons'.

${ }^{145}$ Regulation 2016/679, art 83. Due to the peculiarities of their legal system, in Denmark and Estonia special procedures will apply such that fines will be initiated by a DPA but imposed by the Courts. See Regulation 2106/679, recital 165 and art 83 (9).

${ }^{146}$ Regulation 2016/679, art 83 (1).

${ }^{147}$ Regulation 2016/679, art 52 (4).

${ }^{148}$ See Regulation 2016/679, Chapter VII, Section 2.
} 
are necessary to reconcile the right to the protection of personal data with the freedom of expression and information', whilst Recital 153 stresses that such derogations should be those 'necessary for the purpose of balancing these fundamental rights'.

Notwithstanding the clear family resemblances here with Article 9 and Recital 37 of Directive 95/46, the transposition of this part of the GDPR's derogatory scheme nevertheless provides the EU/EEA, its Member States and indeed DPAs themselves with a unique opportunity to reengage with the fundamental balancing objective of the law here and also to reassess its practical functioning. Indeed, as if to emphasize this point, Article 85(3) requires each Member State to ensure that they notify the Commission without delay of 'those provisions of its law which it has adopted' pursuant to Article $85(2) .{ }^{149}$ In light of the aims not just of Article 85 but also the GPDR as a whole, it would also be valuable for the new European Data Protection Board to revisit the Working Party's existing very short 1997 Recommendation on 'Data Protection law and the media' ${ }^{150}$ with one providing a rigorous and in-depth analysis. Such a 'soft law' instrument could encourage a more consistent and balanced approach, thereby going some way to meeting one of the key recommendation of the European Commission's High Level Group on Media Freedom and Pluralism namely that, in light of the evolving nature of the European media landscape, it was 'particularly important to adopt minimum harmonization rules covering cross-border media activities on areas such as ... data protection'. ${ }^{151}$

\footnotetext{
${ }^{149}$ Any subsequent amendment affecting these provisions must be similarly notified. Perhaps also to underline that this derogatory scheme is in no sense designed to remove journalism entirely from the reach of data protection, art 83(5)(d) rather problematically also provides that breach of the obligations in this area should attract DPA administrative fines of up to $€ 20 \mathrm{M}$ (or in the case of commercial undertakings up to $4 \%$ of the total worldwide annual turnout if this is higher).

${ }^{150}$ See note 35 .

${ }^{151}$ European Commission, High Level Group on Media Freedom and Pluralism, A Free and Pluralistic Media to Sustain European Democracy (2013), p. 3 (https://ec.europa.eu/digital-single-market/sites/digitalagenda/files/HLG\%20Final\%20Report.pdf).
} 
Turning to the substantive and procedural contours of reform in this area, in light of their mission to protect the privacy and other individual rights implicated by personal information processing, it is important that both data protection law and even the DPAs themselves retain a role even as regards professional journalistic activity. Thus, notwithstanding a greatly changed social and technological context, it remains true that the use of personal information by the mass media can inflict great harms on individuals, which on some occasions are unjustified. The disturbing events concerning the blagging and hacking of private personal data which prompted the setting up by the UK in 2011 of the Leveson Inquiry into the Culture, Practices and Ethics of the Press is one good example of this. ${ }^{152}$ The case for a continuing role for DPAs in this area has also been enhanced by the growing convergence between professional journalism and many other types of information processing as highlighted, for example, by the rise of citizen journalism, new platforms for blogging and microblogging, data journalism and ever more powerful and potentially intrusive forms of media archiving. Within this increasingly overlapping context, DPAs have a particular role and responsibility for ensuring a coherent and engaged response across the board. At the same time, it is clearly vital that regulators take free expression rights fully into account both in relation to professional journalism and, in fact, also as regards many other activities which involve the dissemination of information, opinions and ideas to the public at large. One possible structural reform, put forward by the UK Leveson Inquiry, which might facilitate both these outcomes would be to ensure that at least the larger DPAs are led by a 'Board of Commissioners' whose individuals are drawn from a range of backgrounds including at least one from the 'media sector'. 153

\footnotetext{
${ }^{152}$ United Kingdom, Leveson Inquiry, An Inquiry into the Culture, Practices and Ethics of the Press: Report (Stationary Office, 2012).

${ }^{153}$ Ibid, p. 1110.
} 
Turning to the detail of statutory law, it is also clear that the provisions formally applicable to journalism in many Member States are far too onerous to effect an appropriate balance between free speech and data protection here. For example, it is manifestly unacceptable that, as detailed above and irrespective of the public interest, statutory stipulations in almost one third of DPA jurisdictions appear to simply prohibit journalists from gathering any so-called 'sensitive' personal data (including political opinions and criminal convictions) absent waiver from the data subject. Such provisions are not only a direct threat to the secure enjoyment of a fundamental liberty but also inevitably mean that this law does not provide a credible guide to what standards journalists should be expected to adhere to when processing personal information. ${ }^{154}$ Especially given the empirical findings in this article which indicate that the stringency or otherwise of statutory law may still exercise a powerful influence over the extent to which data protection is enforced against journalists, it is imperative that Member States when transposing Article 85 (2) of the GDPR craft clear provisions here which ensure that the essence of both data protection and free speech is genuinely respected and that in each specific case a proportionate balance between the two is attained. ${ }^{155}$ Whilst there is clearly a wide margin of appreciation for Member States within this sensitive area, a crucial metric of the legitimacy of significant derogations from default substantive data protection here must be some kind of assessment of the public interest served by the journalistic activity and information at issue, together with the extent to which it will or may be impeded by this default.

Member States may also wish to place special emphasis on those aspects which, as detailed above, have in practice garnered particular attention from DPAs such as the disclosure of certain types of sensitive and related categories of data and also other

\footnotetext{
${ }^{154}$ Conversely, in some Member States journalism is in effect exempted from all substantive data protection liability irrespective both of its impact on data subjects and on how unfair its processing of data might be. This is similarly not in keeping with the purpose of European data protection.

${ }^{155}$ Such standards are set down inter alia in Article 52 of the Charter of Fundamental Rights of the EU.
} 
information (e.g. personal identification numbers) the confidential treatment of which may be seen as integral to social and economic life. Certainly, the European Data Protection Board should reflect further on such examples in any reformulated Recommendation in this area. A focus both on ensuring the essence of regulatory oversight and ensuring substantive proportionality should also inform the specification of DPA powers here. As indicated above, a clear majority of Member States do not formally currently limit DPA powers here in any way. Nevertheless, DPA default powers of investigation and intervention sit in an uneasy relationship with long-cherished procedural safeguards for free speech, especially as regards prior restraint and licensing. ${ }^{156}$ Under the GDPR, the default powers of DPAs will be specified in much greater detail at pan-European level so as to include inter alia obtaining 'access to all personal data and to all information necessary for the performance of its tasks' ${ }^{157}$ ordering 'a temporary or definitive limitation including a ban on processing, ${ }^{158}$ and imposing an 'administrative fine ... depending on the circumstances of each individual case'. ${ }^{159}$ As a result, this tension will become even more acute. Given this, Member States should provide statutory limits to the regulatory powers of DPAs over journalistic and other special expression whilst ensuring that such powers as remain are sufficient to enable timely and effective protection of data subjects here, thus respecting the data protection's essence including that 'compliance ... be subject to control by an independent authority'. ${ }^{160}$ The exercise of such powers should also seek to synergize with any self-regulatory accountability mechanism substantially overlapping with that of the data protection authority. Nevertheless, whilst this aspect may have particular salience for professional journalistic actors, DPAs must take into full account the serious concerns raised about the practical functioning of many such mechanisms in the journalistic sector.

\footnotetext{
${ }^{156}$ Barendt, Eric, Freedom of Speech (Oxford: OUP) (2 ${ }^{\text {nd }}$ Edition) (2005), p. 117.

${ }^{157}$ Regulation 2016/679, art 58 (1) (e).

${ }^{158}$ Ibid, art. 53 (2) (f).

${ }^{159}$ Ibid, art. 53 (2) (i).

${ }^{160}$ EU Charter, art. 8 (3).
} 
Finally, there must be a renewed emphasis on ensuring the practical effectiveness and transparency of DPAs' own oversight and enforcement efforts as regards the journalistic sector. Although further research on this issue would be desirable, it is clear that the empirical evidence presented in this article raise serious concerns in this regard. Even confining the analysis to those DPAs operating in jurisdictions which place significant substantive data protection obligations on journalists and grant them serious regulatory powers, many reported through the DPA survey either very limited or even no enforcement here. Moreover, whilst there were clear examples of potentially over-bearing and disproportionate actions, the bulk of the DPA website review data suggested only patchy and limited activity. Far from the 'effective and complete protection of data subjects, in particular of their right to privacy ${ }^{161}$ spoken about in CJEU case law, it seems more likely that the track record of many DPAs mirrors to a greater or lesser degree the type of 'regulatory failure' ${ }^{, 62}$ identified by the Leveson Inquiry in relation to the UK DPA. Any step-change in practice here will clearly depend on Member States providing DPAs with more than the relatively meagre resources they generally have at their disposal currently. However, as the correlations run in the previous section vividly indicated, better resourcing will not by itself be sufficient. Instead, a strong internal commitment by DPAs to make a difference for data subjects in this area is also likely to prove necessary. Again, this is something which both DPAs individually and the newly-constituted European Data Protection Board collectively should further consider.

\section{IX - Conclusions}

\footnotetext{
${ }^{161}$ C-131/12 Google Spain at [38].

${ }^{162}$ United Kingdom, Leveson Inquiry, note 86, p. 1107.
} 
European data protection aims to create an 'equivalent ${ }^{163}$ European space for the processing of personal data within which 'the fundamental rights and freedoms of natural persons, and in particular their right to privacy' are safeguarded. ${ }^{164}$ In recognition of its serious potential to interfere with this objective, professional journalistic activity is not exempted from its scope. Instead, and in recognition of the inherently conflicting nature of data protection and free expression, article 9 of Directive 95/46 mandates that all EEA Member States ensure a careful balancing of rights in this area. In reality, Member State transposition of this provision into their statutory law has been highly divergent.

Nevertheless, a clear majority continue to subject journalism to various fairly stringent substantive data protection standards and also to regulatory oversight and control by a Data Protection Authority (DPA). The latter are a mandatory feature of European data protection, in practice constituting 'the main actors protecting data protection rights' ${ }^{165}$ In light of these facts, this article elucidated and explored the enforcement track-record of DPAs in the professional journalistic sector since the transposition of Directive 95/46. This was achieved through the analysis of responses to a questionnaire of DPAs..to which some 25 (over $80 \%$ ) of national and 6 regional regulators responded, together with a review of material readily available on the websites of all national DPA websites and those regional bodies which had responded to the questionnaire. In addition, the article drew on wider research on the interface between EU data protection and public freedom of expression including a systematic analysis of local statutory data protection law as applicable to journalism and DPA questionnaire responses concerning both the resourcing they had available for their activities and on their stance and enforcement activity as regards 'new' internet media activities such as blogging, social networking and rating websites.

\footnotetext{
${ }^{163}$ Directive 95/46, recital 8.

${ }^{164}$ Directive 95/46, art. 1.

${ }^{165}$ EU, Agency for Fundamental Rights, Access to Data Protection Remedies in EU Member States (2013), p. 9 (http://fra.europa.eu/sites/default/files/fra-2014-access-data-protection-remedies_en.pdf).
} 
The article demonstrated that in the area of journalism, European data protection regulation may be considered 'down but not out'. DPA enforcement here has certainly been much more limited than the formal statutory provisions in this area would suggest. In sum, not did only around half of DPAs report enforcement activity in this area, but the great majority of them indicated that they had only intervened in this way in regard to one or two aspects of the data protection scheme. The DPA website review confirmed this patchy picture, whilst also highlighting some rather problematic divergences in terms of how EEA DPAs went about reporting their enforcement efforts. Nevertheless, both sets of data also demonstrated that regulators have far from entirely ignored this area. To the contrary, at 54\% the proportion of DPA questionnaire respondents who reported enforcement here was higher than the reported level of enforcement as regards any category of 'new' media actor including bloggers, rating websites and even street mapping services. Moreover, the DPA website review uncovered significant (and in a few instances even potentially over-bearing) efforts at enforcement, especially as regards journalistic processing of certain sensitive and related categories of data as well information - such as national identification numbers - the confidential treatment of which can be considered particularly critical to the proper functioning of social and economic life. The gap between the purported guarantees set down in statutory law and the actual activity of DPAs may be explained in some cases by the clear conflict between the former and journalistic rights to freedom of expression which DPAs, at least in principle, appear committed to uphold if necessary, notwithstanding contrary statutory instruction. Nevertheless, the data also disclosed limited evidence of activity to enforce requirements - such as taking care not to publish inaccurate material and answering subject access requests - which either are generally understood, or at least which DPAs themselves claim, to present little conflict with legitimate free speech. Moreover, statistical analysis demonstrated that the relative stringency of local statutory law was still very strongly 
correlated with both the presence and extent of DPA enforcement efforts. In contrast, and surprisingly, there was no evidence that better resourcing of DPAs was associated with more activity. Interestingly, as regards this latter aspect, the very same patterns were found as regards enforcement against 'new' internet media, even though divergences in formal law between different EEA jurisdictions here are generally considered much less significant. This may suggest that an important catalyser of enforcement here may ultimately be the strength of a DPA's own ideological commitment to intervening in such sensitive and controversial territory. Whilst this commitment may be correlated with the stringency of local statutory data protection law applicable to professional journalism, it would ultimately operate semi-independently from it.

The EU has now agreed to replace Directive 95/46 with a new General Data Protection Regulation (GPDR) which will apply from May 2018. The transposition of the GDPR's interface with journalism and cognate free speech (Art. 85 (2)) provides a unique opportunity to address the various issues identified in this research. Whilst not excluding professional journalism entirely either from substantive data protection or regulatory oversight, Member State law must ensure that the essence of both the right to data protection and freedom of expression is respected and a proportionate balance is secured between the two. Meanwhile, European DPAs should reappraise their oversight and enforcement activity as regards professional journalism in order to ensure that data subject remedies are genuinely effective at a practical level. Although most of this work should take place at the national level, there would be value in European DPAs providing more collective guidance through a Recommendation on this topic by the new European Data Protection Board. Such actions would build a more coherent and effective regime in this area, thereby protecting both data subject rights where necessary and ensuring that journalistic free expression rights are also safeguarded and secured. 
Appendix: EEA DPA Enforcement and Professional Journalism: Quantitative Dataset

\begin{tabular}{|c|c|c|c|c|c|c|c|c|c|c|c|c|c|}
\hline \multirow[b]{2}{*}{ DPA Jurisdiction } & \multicolumn{6}{|c|}{ DPA Survey: Enforcement Codings } & \multirow{2}{*}{$\begin{array}{l}\text { DPA } \\
\text { Website } \\
\text { Data }\end{array}$} & \multicolumn{3}{|c|}{ Formal Law Measures } & \multicolumn{3}{|c|}{ DPA Budget Measures } \\
\hline & Register & Accuracy & $\begin{array}{l}\text { Data } \\
\text { Access }\end{array}$ & $\begin{array}{l}\text { General: } \\
\text { Unauthorized }\end{array}$ & $\begin{array}{l}\text { General: } \\
\text { Other }\end{array}$ & Total & & Substance & $\begin{array}{l}\text { Regulatory } \\
\text { Jurisdiction }\end{array}$ & $\begin{array}{l}\text { Combined } \\
\text { Measure }\end{array}$ & Gross (€) & $\begin{array}{l}\text { Per Capita } \\
(€)\end{array}$ & $\begin{array}{l}\text { Combined } \\
\text { Index }\end{array}$ \\
\hline Austria & 0 & 0 & 0 & 0 & 0 & 0 & 0 & 0.1 & 0 & 0 & 1200000 & 0.14 & 0.04 \\
\hline Belgium & 0 & 1 & 0 & 0 & 0 & 1 & 0 & 0.59 & 1 & 0.59 & 5800000 & 0.52 & 0.17 \\
\hline Bulgaria & Text & Text & Text & Text & Text & Text & 1 & 0.68 & 1 & 0.68 & 1506024 & 0.21 & 0.05 \\
\hline Croatia & & & & & & & 0 & 1 & 1 & 1 & & & \\
\hline Cyprus & 0 & 0 & 0 & 1 & 1 & 2 & 1 & 0.65 & 1 & 0.65 & 257352 & 0.30 & 0.02 \\
\hline Czech Republic & Text & Text & Text & Text & Text & Text & 0 & 1 & 1 & 1 & 6299760 & 0.60 & 0.18 \\
\hline Denmark & & & & & & & 0 & 0.15 & 0.5 & 0.075 & & & \\
\hline Estonia & 0 & 0 & 1 & 0 & 0 & 1 & 0 & 0.67 & 1 & 0.67 & 378797 & 0.29 & 0.02 \\
\hline Finland & 0 & 0 & 0 & 0 & 0 & 0 & 0 & 0 & 1 & 0 & 1800000 & 0.33 & 0.06 \\
\hline France & 0 & 0 & 0 & 0 & 0 & 0 & 0 & 0.53 & 1 & 0.53 & 17200000 & 0.26 & 0.46 \\
\hline $\begin{array}{l}\text { Germany } \\
\text { Federal }\end{array}$ & 0 & 0 & 0 & 0 & 0 & 0 & 0 & 0.03 & 0 & 0 & & & \\
\hline $\begin{array}{l}\text { Germany } \\
\text { Brandenburg }\end{array}$ & 0 & 0 & 0 & 0 & 0 & 0 & 0 & 0.03 & 0 & 0 & 1858534 & 0.65 & 0.07 \\
\hline $\begin{array}{l}\text { Germany } \\
\text { Mecklenberg- } \\
\text { Vorpommern } \\
\end{array}$ & 0 & 0 & 0 & 0 & 0 & 0 & 0 & 0.03 & 0 & 0 & 1268525 & 0.69 & 0.05 \\
\hline $\begin{array}{l}\text { German } \\
\text { Rhineland- } \\
\text { Palatinate } \\
\end{array}$ & 0 & 0 & 0 & 0 & 0 & 0 & 0 & 0.03 & 0 & 0 & 1921641 & 0.38 & 0.06 \\
\hline $\begin{array}{l}\text { Germany } \\
\text { Schleswig- } \\
\text { Holstein } \\
\end{array}$ & 0 & 0 & 0 & 0 & 0 & 0 & 0 & 0.03 & 0.5 & 0.015 & 1997249 & 0.60 & 0.07 \\
\hline Gibraltar & 0 & 0 & 0 & 0 & 0 & 0 & 0 & 0.33 & 1 & 0.33 & 148357 & 4.95 & 0.16 \\
\hline Greece & 0 & 0 & 0 & 1 & 1 & 2 & 1 & 0.84 & 1 & 0.84 & 1816000 & 0.17 & 0.05 \\
\hline Hungary & 0 & 1 & 1 & 1 & 0 & 3 & 1 & 0.95 & 1 & 0.95 & 1606381 & 0.16 & 0.05 \\
\hline Iceland & & & & & & & 1 & 0.06 & 0 & 0 & & & \\
\hline Ireland & 0 & 0 & 1 & 0 & 0 & 1 & 1 & 0.34 & 1 & 0.34 & 2200000 & 0.48 & 0.07 \\
\hline Italy & 0 & 1 & 1 & 1 & 1 & 4 & 1 & 0.65 & 1 & 0.65 & 8500000 & 0.14 & 0.23 \\
\hline
\end{tabular}




\begin{tabular}{|c|c|c|c|c|c|c|c|c|c|c|c|c|c|}
\hline Latvia & 0 & 1 & 0 & 0 & 0 & 1 & 0 & 0.67 & 1 & 0.67 & 392247 & 0.19 & 0.02 \\
\hline Liechtenstein & 1 & 0 & 0 & 1 & 0 & 2 & 0 & 0.88 & 1 & 0.88 & 595499 & 16.17 & 0.52 \\
\hline Lithuania & 0 & 0 & 0 & 1 & 1 & 2 & 1 & 0.63 & 0.5 & 0.32 & 554624 & 0.19 & 0.02 \\
\hline Luxembourg & Text & Text & Text & Text & Text & Text & 0 & 0.68 & 1 & 0.68 & 1600000 & 2.98 & 0.13 \\
\hline Malta & Text & Text & Text & Text & Text & Text & 0 & 0.33 & 0.5 & 0.165 & 275000 & 0.65 & 0.03 \\
\hline Netherlands & 0 & 0 & 0 & 1 & 0 & 1 & 1 & 0.38 & 0 & 0 & 7500000 & 0.45 & 0.21 \\
\hline Norway & & & & & & & 0 & 0 & 1 & 0 & & & \\
\hline Poland & 0 & 0 & 0 & 0 & 0 & 0 & 0 & 0.33 & 1 & 0.33 & 3569087 & 0.09 & 0.10 \\
\hline Portugal & 0 & 0 & 0 & 0 & 0 & 0 & 0 & 0.77 & 1 & 0.77 & 2700000 & 0.26 & 0.08 \\
\hline Romania & & & & & & & 0 & 0.83 & 1 & 0.83 & & & \\
\hline Slovakia & 0 & 0 & 0 & 1 & 1 & 2 & 0 & 0.93 & 1 & 0.93 & 658716 & 0.12 & 0.02 \\
\hline Slovenia & 0 & 0 & 1 & 1 & 1 & 3 & 1 & 0.93 & 1 & 0.93 & 933333 & 0.45 & 0.04 \\
\hline Spain Federal & & & & & & & 1 & 1 & 1 & 1 & & & \\
\hline Spain Catalonia & 0 & 0 & 0 & 1 & 1 & 2 & 0 & 1 & 0.5 & 0.5 & & & \\
\hline Sweden & 0 & 0 & 0 & 0 & 0 & 0 & 0 & 0 & 1 & 0 & 4922606 & 0.52 & 0.14 \\
\hline UK & Text & Text & Text & Text & Text & Text & 1 & 0.35 & 0.5 & 0.175 & 19233140 & 0.30 & 0.51 \\
\hline
\end{tabular}

Note: As specified in the body of the article, the budget figures for each of the German Länder DPAs have been augmented by notionally allocating a portion of the Federal DPA budget to them, pro-rated on their population size within Germany. 